\title{
Dinâmica da paisagem e proposição de cenários ambientais: um estudo da planície costeira de Estância, Sergipe, Brasil *
}

\author{
Landscape dynamics and environmental scenarios: a study of Estancia \\ coastal plain, Sergipe, Brazil
}

\author{
Anízia Conceição Cabral de A. Oliveira ${ }^{\circledR, 1}$, Rosemeri Melo e Souza ${ }^{1}$
}

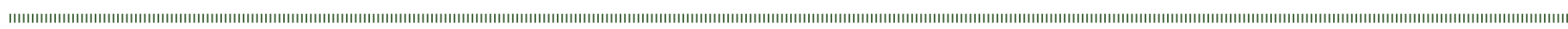

\section{RESUMO}

Este trabalho objetivou desenvolver cenários ambientais para a Planície Costeira do município de Estância localizado na porção sul do Estado de Sergipe como subsídio ao ordenamento territorial. O estudo consistiu na compreensão de como se dá o funcionamento da paisagem a partir da análise dos seus sistemas componentes, da sua estrutura espacial e de suas modificaçóes no tempo como alicerce para o desenvolvimento de uma proposta de uso recomendado, aqui designada como cenário de uso recomendado e, com base nele, o uso pretendido, considerado como cenário exploratório, cuja análise envolve as perspectivas de ocupação para o futuro a partir das consequências das opçóes sugeridas.

No intuito de propiciar as bases para o planejamento da ocupação da área estudada, desenvolveu-se, primeiramente, a delimitaçáo e classificação de unidades e subunidades de paisagens com base em parâmetros relacionados à morfologia, às litoestruturas aliados aos aspectos da cobertura vegetal e do uso e ocupação do solo. Num segundo momento, foi realizada a identificação dos níveis de ocupação de cada compartimento por meio da análise das diversas formas de uso e ocupação do solo e dos agentes e processos físicoambientais mais atuantes.

Nesse contexto, identificados os distintos níveis de ocupação, estes relacionados a processos em sua maior parte de natureza degradante definidores das mudanças ambientais verificadas, puderam ser alcançadas a proposta de uso recomendado e, a partir da proposiçáo, a análise das consequências para o funcionamento da paisagem litorânea em estudo.

Palavras-chave: Cenários Ambientais; Planejamento Ambiental; Planície Costeira.

\section{ABSTRACT}

This work aims to build environmental scenarios for the coastal plain of the Estancia/Sergipe. The purpose of this study is in understanding how is the functioning of the landscape from the analysis its component systems, their spatial structure and its changes over time as the foundation for the development of two scenarios: recommended scenario and, on the based thereon, the intended use, called of exploratory scenario, which involves the prospects for the future from of the consequences of the suggested options.

@ - Autor correspondente: aniziacaoliveira@gmail.com

1 - Universidade Federal de Sergipe, Grupo de Pesquisa em Geoecologia e Planejamento Territorial GEOPLAN/UFS/CNPq, Av. Marechal Rondon, S/N, Pólo de Gestão/Pós-Graduação, sala 01. São Cristóvão, SE, Brasil. 
In order to provide the basis for the planning of the occupation of the area studied, initially, we developed the definition and classification of units and subunits of landscapes based on morphological parameters allied to aspects of the vegetation and of the use and occupation the soil. Secondly, the analysis of the various levels of the occupation of each compartment was made by analysis of the various forms of land use and agents and environmental processes most active in the study area.

In this context, after identifying the different levels of occupation, the proposition of the scenarios through different descriptions of possible future events and their consequences for the functioning of the coastal landscape could be achieved.

Keywords: Environmental Scenarios; Environmental Planning; Coastal Plain

\section{INTRODUÇÃO}

Cenários são instrumentos de análise que permitem o conhecimento da evoluçáo da paisagem a partir da interpretação dos rumos e das velocidades das transformaçóes no espaço. Por possibilitarem a reflexão sobre as consequências das opçóes de usos e formas de ocupação do território, ajudam a orientar as açóes atuais e futuras do homem.

A relação entre a proposição de cenários e o conhecimento das mudanças na paisagem é intrínseca. Em estudos ambientais, a investigação das alterações numa determinada paisagem, movidas tanto por processos naturais quanto por processos de influência antrópica, ou simultaneamente por ambos, automaticamente reporta-se à perspectiva dinâmica.

Considerando que o estudo da dinâmica da paisagem permite o conhecimento de sua evoluçáo, de maneira geral, pode-se dizer que investigar a evolução da paisagem é tratar da análise de cenários.

Destacando o viés do planejamento, Santos (2004: p.50) enfoca que cenários nada mais são do que "interpretaçōes de momentos em uma paisagem dentro de uma escala temporal, visando auxiliar agentes de planejamento a compreender a dinâmica da área e os problemas ambientais consequentes".

Santos (2004: p.51) trata dos cenários numa ótica que considera os anseios dos agentes envolvidos e vislumbra as dimensóes passado, presente e futuro, cada uma permitindo interpretaçôes particulares de fatos: do passado - o que foi (cenário passado); do presente - o que é (cenário real) e do futuro - o que será se medidas não forem tomadas (cenário futuro tendencial), como deveria ser (cenário futuro ideal, frente às potencialidades e restriçôes biofísicas), como gostaria que fosse (cenário futuro desejado) e o que pode realmente ser (cenário futuro possível, alternativo, frente às restriçóes biofísicas, às aspiraçóes e às limitações socioeconômicas e administrativas).

No tocante à perspectiva do futuro, Santos (2004: p.53) ressalta que os cenários futuros representam "simulaçôes de diferentes situações, prognóstico das condições ambientais em um tempo mais ou menos próximo".

Conforme Freitas Filho (2001: p.9) quanto à tipologia de cenários futuros, são comuns três classificaçôes:

- Cenário Tendencial que abarca a dimensão extrapolativa (onde chegaremos?), ou seja, o futuro é a extrapolaçáo do passado com caráter determinista; refere-se ao que tende a acontecer, apresenta a evolução futura com base em projeçóes de tendências históricas, dando noção de continuidade;

- Cenário Exploratório - cuja dimensão envolve a noção de complexidade, acaso e rupturas, refere-se ao que pode acontecer, o futuro tem possibilidades alternativas de evolução dada pela conjugaçáo de forças do presente e do passado, (onde poderemos chegar?); e

- Cenário Normativo - em que a dimensão se baseia no futuro que pode ser construído, diz respeito ao que deve acontecer segundo os valores dos envolvidos com a construção do cenário, apresenta aspectos desejáveis e pode se confundir com a visão de futuro desejada, (onde queremos chegar?).

O Ministério do Meio Ambiente em seu documento Projeto Orla: manual de gestão (Zamboni \& Vilanova, 2006), reconhecendo a existência de vários cenários, destaca o tendencial e o desejado. Já Oliveira \& Rodrigues (2009) dão ênfase ao cenário tendencial considerado pelos autores como as possibilidades de transformaçóes que a região de estudo estará propensa, sejam elas de origem natural ou antrópica e o cenário exploratório, o qual procura analisar as consequências das opçôes escolhidas.

Sobre metodologias para cada proposta de cenários Costa e Nascimento (2007: p.50) afirmam que o cenário tendencial faz uso de projeçóes matemáticas e econométricas literalmente baseadas no passado, o cenário exploratório, por sua vez, precisa extrapolar as tendências e lidar com mudanças do ambiente, já um cenário normativo, conta mais com os valores dos participantes do que com indicaçôes históricas ou fatos portadores de futuro.

Bolós (1992) expóe que para a construção de cenários devem ser conhecidos da paisagem objeto de estudo: a direçáo e velocidade do desenvolvimento natural dos elementos bióticos e abióticos do geossistema; as mudanças dos elementos do subsistema geoecológico (elementos abióticos e bióticos) sob a influência das atividades econômicas da sociedade; o desenvolvimento dos elementos antrópicos dentro do sistema socioeconômico.

Em se tratando de uma abordagem direcionada à avaliação ambiental, os estudos baseados em cenários prospectivos devem oferecer um quadro fundamental da inter-relação entre fatores e processos dinâmicos atuantes na paisagem proporcionando, a partir da análise dos componentes estruturais e fatores condicionantes das mudanças, o estabelecimento de premissas e um caminho concreto de decisões voltadas ao melhor planejamento e gestão dos ambientes estudados.

A Zona Costeira é marcada pela convergência de diversos usos e rápido dinamismo de ocupação. Historicamente, a Zona Costeira vem-se caracterizando por uma diversidade 
de atividades vinculadas a vários tipos de usos como o portuário, o agrícola, o de cunho industrial, usos relacionados ao transporte, à exploração petrolífera, ao valor paisagístico como o turístico, o comercial, o recreacional que fazem reunir uma densa infraestrutura e predominar fortes zonas de concentração populacional.

Assim como são múltiplas as atividades, derivadas da alta densidade populacional, da expansão urbana e industrial descontrolada, da especulação imobiliária e da intensificação do turismo são também significativos as pressóes e os conflitos delas decorrentes.

Em se tratando da elevada conflitualidade presente nestas áreas, Dias et al (2009: p.4) ressaltam que “(...) interesses portuários competem com as atividades tradicionais (pesca artesanal, agricultura, etc.), interesses econômicos competem com a conservaçâo ambiental, turismo de massas compete com a manutenção dos valores culturais das populaçôes indigenas, obras fixas de proteção costeira competem com os valores paisagisticos naturais, esportes radicais competem com as práticas balneares, atividades industriais competem com o turismo de Natureza".

Usos indevidos e formas de ocupação desordenadas quando afetam o equilíbrio de um dos ambientes pertencentes à Zona Costeira acabam comprometendo o sistema costeiro como um todo. Tais usos e ocupaçóes impróprios vêm provocando a descaracterização de muitos sistemas biofísicos, transformando ambientes, antes em condiçôes de certa estabilidade em paisagens degradadas, cujos impactos gerados interferem diretamente na qualidade ambiental da Zona Costeira.

$\mathrm{Na}$ Zona Costeira de Sergipe elementos naturais e humanos condicionam a existência de unidades de paisagem que se particularizam conforme as suas características de composição e funcionamento. No Litoral Sul do estado, sobretudo no município de Estância, ambientes naturais marcantes vêm sendo degradados por conta de atividades humanas diferenciadas cujo padrão dispare de ocupação determina a rapidez e a intensidade das transformaçóes.

Do ponto de vista da apropriaçáo do solo, o Litoral Sul apresenta uma estrutura não consolidada, mas que vem se definindo pelo crescente processo de especulação imobiliária. As atividades de veraneio, marcadas por uma certa sazonalidade, aos poucos vêm sendo substituídas pelo adensamento de equipamentos humanos. Tais atividades conjugadas ao desenvolvimento da atividade turística vêm induzindo, ao longo do tempo, empreendimentos imobiliários em quase toda a porção sul provocando a transformação rápida do espaço.

Nesse contexto, considerando a problemática que envolve os ambientes biofísicos sob a atuação de processos de ocupação desordenada e tendo em vista que cresce cada vez mais a preocupação com o planejamento da ocupação territorial, a regulação dos usos no Litoral com base no nível de fragilidade ambiental dos sistemas e preservação da integridade dos ambientes naturais destaca-se como orientação para estudos que focalizem a proposição de cenários como instrumentos favoráveis ao direcionamento de açóes visando o ordenamento territorial.

Como ferramenta de planejamento e numa ótica voltada ao ordenamento dos usos, o desenvolvimento de cenários oferece subsídios efetivos para o processo de determinação de pontos de maiores e menores restrições ao uso, dos limites de resiliência dos ambientes afetados por determinado tipo e intensidade de degradação visando à indicação de alternativas de manejo.

É nesse sentido que o presente trabalho objetivou construir cenários representativos das mudanças verificadas na paisagem costeira do município de Estância (Figura 01) pertencente ao Litoral Sul de Sergipe a partir da identificação e caracterização dos elementos e processos físicoambientais mais atuantes e da análise das formas de uso e ocupação e dos diversos níveis de ocupação delas derivados.

\section{MATERIAIS E MÉTODOS}

No presente trabalho foram desenvolvidos dois tipos de cenários: o cenário recomendado, proposta de uso recomendado mediante a análise da configuração atual do espaço pelo padrão vigente de uso e ocupação e cenário exploratório, baseado em Oliveira \& Rodriguez (2009), designado para se referir ao uso pretendido, com a finalidade de indicar o uso sustentável frente às perspectivas de ocupação para o futuro.

O desenvolvimento dos cenários (cenário recomendado e cenário pretendido) foi nesta pesquisa possibilitada primeiramente pela delimitação e classificação de unidades e subunidades de paisagens com base em parâmetros relacionados à morfologia (caracterização da forma), às litoestruturas e à fisiologia (caracterização dos atributos físicos) aliados aos aspectos da cobertura vegetal e do uso do solo, o que permitiu, num segundo momento, a identificação dos níveis de ocupação de cada compartimento.

A compartimentação das unidades de paisagem da área de estudo utilizou como critério-chave a base de dados de geomorfologia do Atlas Digital sobre Recursos Hídricos de Sergipe (SEPLAN/SRH, 2004). As informaçóes sobre geologia, solos, altimetria, importantes por subsidiarem as análises, também foram extraídas do referido Atlas.

A partir desta classificação oficial é que puderam ser compartimentadas as subunidades de paisagem a partir da associação das características geomorfológicas, com as geológicas, pedológicas, de declividade do terreno, bem como do uso e cobertura vegetal resultando, mediante a integração das informações relacionadas a estes fatores, diferentes categorias de ambientes.

Assim, para a elaboração do mapa de unidades e subunidades da área de estudo, cada polígono foi gerado por meio da combinação dos referidos temas, sendo desenvolvido, para isso, um inventário das características físicas, biológicas e de uso do solo através da identificação e caracterização dos agentes e processos físicoambientais mais atuantes na paisagem, sendo que, para a divisão em subunidades foi adotado como critério-chave a identificação dos níveis de ocupação do solo mediante a análise dos tipos e processos de uso em cada unidade da Planície Costeira.

Destaque se faz ao fato de que as diferentes unidades geomorfológicas têm níveis de ocupação diferentes e essa diferenciação origina-se da relação entre uso do solo e as características morfológicas dos atributos físicos que comumente são determinantes para a existência dos tipos de uso e ocupação encontrados. 


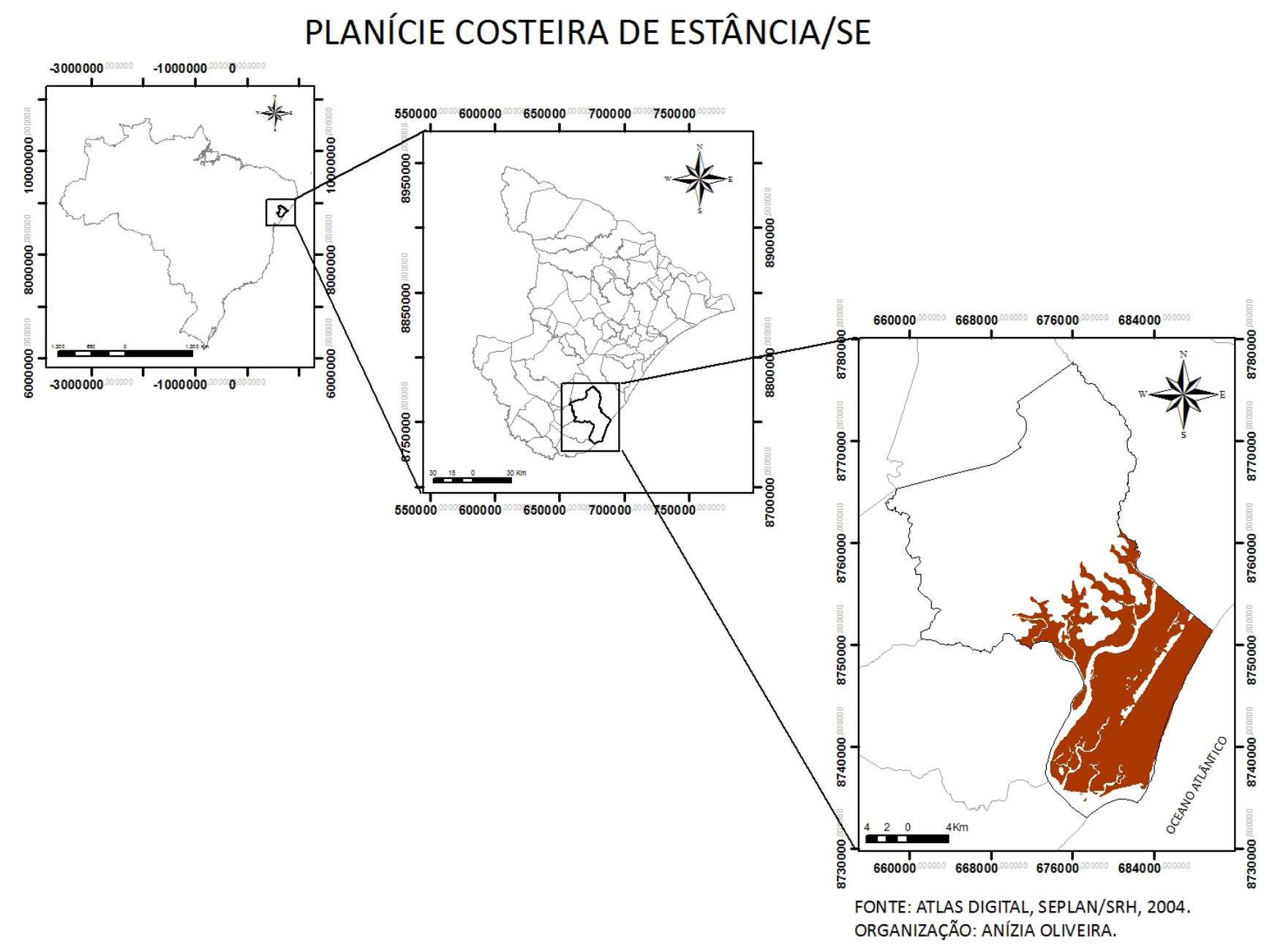

Figura 01. Localização da área de estudo.

Figure 01. Location of the study area.

Com base na identificação e análise do padrão de uso e ocupação em que se consolida a organização do espaço foram analisados os processos geoecológicos degradantes da Planície Costeira do município de Estância por meio do enfoque funcional proposto por Rodriguez, Silva e Cavalcante (2004) que contempla a análise da dinâmica funcional da paisagem. Segundo estes autores (p. 124), o enfoque funcional objetiva explicar "como a paisagem é estruturada, quais são as relaçôes funcionais de seus elementos, por que está estruturada de determinada maneira (relaçóes genéticas ou causais) e para que está estruturada de certa forma (quais as funçóes naturais e sociais)".

$\mathrm{O}$ enfoque funcional proposto pelos autores é fundamentado nos principais marcos teórico-conceituais:

- O entendimento de que na paisagem, todos os seus elementos cumprem funçóes determinadas e participam de forma peculiar no seu processo de gênese.

- A busca de uma análise integrada dos componentes antrópicos e naturais a partir de uma caracterizaçáo socioeconômica e geoecológica.

- A sustentação da necessidade de esclarecer os elementos substanciais dos subsistemas, que refletem o sistema das inter-relaçôes externas das paisagens, que dominam sua essência e sua vida. Difícil
Este enfoque fornece procedimentos analíticos que permite descobrir quais as mudanças espaço-temporais ocorrem e quais poderão ocorrer na paisagem, traduzindose numa abordagem adequada ao estudo da dinâmica paisagística, alicerce para a constituiçáo de cenários ambientais.

Oliveira \& Rodrigues (2009: p.306) afirmam que a proposição de cenários ambientais baseia-se na análise e representaçáo de situaçóes de evolução de um ambiente, levando-se em conta o tempo, espaço, interação entre variáveis e a lógica intuitiva e que essa metodologia é de grande importância para o planejamento ambiental, já que analisa em uma perspectiva futura a eficácia das diretrizes propostas.

Nesse contexto, baseado nas definiçóes destes autores, dois tipos de cenários foram desenvolvidos:

- cenário recomendado que, com base nas alteraçóes detectadas na paisagem, no estado de degradação atual e de acordo com a análise da conformidade do uso com a legislação ambiental vigente, retratou as mudanças na paisagem e estabeleceu para cada tipo de problema, quais devem ser as medidas de ordenamento. 
- cenário exploratório que, de acordo com os autores, é criado a partir da proposta de uso recomendado no cenário anterior. Configura-se como um cenário pretendido, pois procurará analisar as consequências das opçôes sugeridas, tendo em vista a consideração das propostas de uso recomendado, referindo-se a possibilidade de futuro numa perspectiva que vislumbra o uso sustentável. Para o desenvolvimento deste cenário foi considerado como horizonte temporal o intervalo de 10 anos.

O mapa de uso e ocupação do solo e os mapas de unidades e subunidades de paisagem foram resultantes da análise da interpretação de ortofotos em escala de 1:10.000, cedidas pela Secretaria de Planejamento (SEPLAN/SE) obtidas em cobertura aerofotogramétrica ocorrida em 2003.

O mapa de uso e ocupação do solo foi desenvolvido a partir de uma chave de interpretação baseada nas definiçóes de Meirelles et al. (1999) que considera as variaçôes de cores, textura, forma, padrōes de drenagem e relevo.

Tal mapa serviu de base para a confecção do mapa de unidade e subunidades de paisagem, o qual apresenta os níveis de ocupação para cada compartimento da Planície Costeira.

Com base na proposta metodológica de Rodriguez, Silva e Cavalcante (2004), foi desenvolvida a análise da interação entre a dinâmica natural e os processos degradantes relacionados aos usos de cada unidade e subunidade de paisagem e assim propostas classes genéricas sobre o nível de modificação dos sistemas naturais.

O Quadro 01 mostra a associação entre as classes referentes à intensidade de modificação dos sistemas naturais, aos níveis de ocupação, bem como, entre os níveis de degradação baseados em Rodriguez et al (2004).

A proposta de cenário recomendado foi desenvolvida mediante a análise do estado de degradação e da concordância do uso com a base legal vigente.

Em âmbito federal, as seguintes regulamentações jurídicas foram consultadas: a Resolução CONAMA No 001, de 23 de janeiro de 1986 que dispóe sobre a Avaliação de Impacto Ambiental; a Resolução CONAMA No 303, de 20 de março de 2002 que estabelece parâmetros, definiçóes e limites de Áreas de Preservação Permanente; o Código Florestal (Lei No 4.771/65) e o Plano Nacional de Gerenciamento Costeiro (Lei No 7.661/88).

$\mathrm{Na}$ esfera estadual foi examinada a Lei No 5.858 de 22 de março de 2006 que dispóe sobre a Política Estadual do Meio Ambiente e institui o Sistema Estadual do Meio Ambiente.

Em se tratando da legislação municipal, orientaram a análise o Plano Diretor do Município de Estância/SE (Lei No 31/2010); o Código Municipal de Meio Ambiente (Lei No $18 / 2008)$ e a Lei No $28 / 2010$ que institui diretrizes para o Parcelamento do Uso do Solo.

Quadro 01. Associação entre as classes referentes à intensidade de modificação dos sistemas ambientais, aos níveis de ocupação e aos níveis de degradação. Níveis de degradação adaptados de Rodriguez et al (2004).

Table 02. Association between the intensity modification of environmental systems, levels of occupation and levels of degradation. Levels of degradation adapted from Rodriguez et al (2004).

\section{Intensidade de modificaçáo dos sistemas naturais}

Não modificados ou levemente modificados

Sem ocupação ou ocupação muito
baixa
$0-20 \%$

Com baixa ocupação $20-40 \%$

Parcialmente modificados

Medianamente modificada a modificada

Com média ocupação $40-60 \%$

\section{Nível de degradação}

Sem ou muito pouca

Pouco degradada,

de leve a moderada

Pouco degradada a degradada. Há perda

parcial da estrutura espacial e funcional mas ainda conservam a capacidade de recuperação

Degradada.

Fortemente modificada Com alta ocupaçáo $60-80 \%$
Há desestruturaçáo dos elementos, perderam a capacidade de recuperação do estado original
Muito fortemente modificada
Com ocupação muito alta $80-100 \%$
Muito degradada

Paisagem esgotada 
A identificação dos níveis de ocupação de cada unidade e subunidade de paisagem da Planície Costeira de Estância e dos níveis de degradação de cada compartimento permitiu a classificação em categorias de ações compatíveis com a situação ambiental de cada classe de uso recomendado (Quadro 02).

Quadro 02. Relação entre as classes de uso recomendado e as açóes prioritárias

Table 03. Relation between use classes and recommended priority actions

\begin{tabular}{cc}
\hline Classes & Açóes \\
\hline Preservação & de Proibição \\
\hline Conservação & de Restrição \\
\hline Recuperação & de Recuperação \\
\hline Passível de ocupação & de Controle \\
\hline
\end{tabular}

Assim, conforme a indicação destas ações, o cenário de usos recomendados para a paisagem da Planície Costeira de Estância contemplou quatro classes:

- De Preservaçáo: classe onde o objetivo principal é a preservação. A prioridade é a manutenção da integridade funcional dos ambientes naturais devido à importância biológica/ecológica. Abrange estratégias de açôes preventivas em conformidade com o disposto na legislação ambiental. Incluemse nesta zona as APPs (cursos d'água, mangues, dunas, praias, restingas). Também fazem parte desta classe os ambientes com alto grau de instabilidade geomorfológica, apresentando risco à ocupação, como exemplo as áreas com relevo fortemente ondulado, propensas a processos erosivos. Envolve a delimitaçáo das áreas non aedificandi atendendo ao disposto na legislação.

- De Conservaçáo: classe onde o objetivo maior é a conservação. Contudo, as áreas pertencentes a esta classe podem ser utilizadas para outros fins. Recomenda-se restringir a ocupação como forma de garantir, dentre outros fatores, a permanência da cobertura vegetal natural. A característica fundante desta classe é a conciliação do desenvolvimento com as vocaçóes das unidades paisagísticas respeitando-se a capacidade de suporte.

- De Recuperaçáo: classe em que se recomenda, conforme Oliveira e Rodrigues (2009: p.311), a recuperação das principais funçóes dos ambientes naturais, nesta classe constam "áreas que foram afetadas por processos antrópicos, que necessitam de recuperação para posteriormente se enquadrarem em alguma categoria de proteção ou conservação acima propostas". Dá-se ênfase a recuperação das áreas dotadas de proteção legal. Os problemas ambientais existentes requerem açóes para manutenção $\mathrm{e}$ melhora da qualidade ambiental.

- Passível de ocupaçáo (ocupaçáo orientada): classe criada para abranger as áreas que podem ser ocupadas tendo como referência os níveis básicos de sustentação da qualidade ambiental. Os usos devem ser orientados. Abrange áreas geomorfologicamente estáveis não apresentando risco à ocupação.

Já o cenário exploratório é um subproduto da proposta de uso do cenário recomendado. Evidencia as consequências dos acontecimentos desencadeados a partir das classes e açôes indicadas no cenário anterior. Como horizonte temporal, foi considerado o intervalo de 10 anos para o seu desenvolvimento.

As classes estipuladas foram as seguintes:

- Área de Preservação Permanente: É constituída por todas as áreas antes pertencentes à classe Preservação do cenário recomendado. Adota as determinaçóes definidas em lei sobre as categorias de proteção da vegetação.

- Paisagem com dinâmica ambiental preservada: Diz respeito à classe Conservaçáo. A principal característica é quanto à conservação de todas as áreas pertencentes a esta categoria do cenário recomendado que no cenário exploratório (uso pretendido) possibilitou a manutenção das características e funçóes naturais dos ambientes biofísicos.

- Paisagem melhorada: Diz respeito à classe Recuperação proposta para o cenário recomendado. No horizonte temporal adotado, as áreas pertencentes a esta classe estarão em conformidade com a legislação ambiental.

- Ocupaçáo rarefeita: Classe criada para enquadrar a faixa de terra ao longo da Rodovia Estadual SE10 que deverá conter baixo adensamento, pois se trata de uma classe que integra a categoria Paisagem com dinâmica ambiental preservada, antes Zona de Conservação.

- Ocupaçáo consolidada: Classe antes representada pelas áreas pertencentes a classe Passível de ocupação. Envolve a consolidação da ocupação por localidades, pastagens e cultivos, mas como indicado no cenário recomendado abrangerá o controle da qualidade ambiental.

Mapas temáticos foram produzidos a partir do software ArcGIS. Para dar suporte ao inventário dos elementos da paisagem e ao trabalho de vetorização das categorias de uso da terra, dos níveis de ocupação, das classes de estado ambiental e dos cenários propostos, levantamentos bibliográficos e cartográficos foram feitos, bem como, realizados trabalhos de campo para checagem das informaçôes e verificações "in loco" das classes mapeadas.

Para uma melhor explanação do que se propóe para o presente artigo, o fluxograma a seguir apresenta o caminho analítico adotado neste estudo. 


\section{CENÁRIOS PARA A PLANÍCIE COSTEIRA DE ESTÂNCIA- SERGIPE}

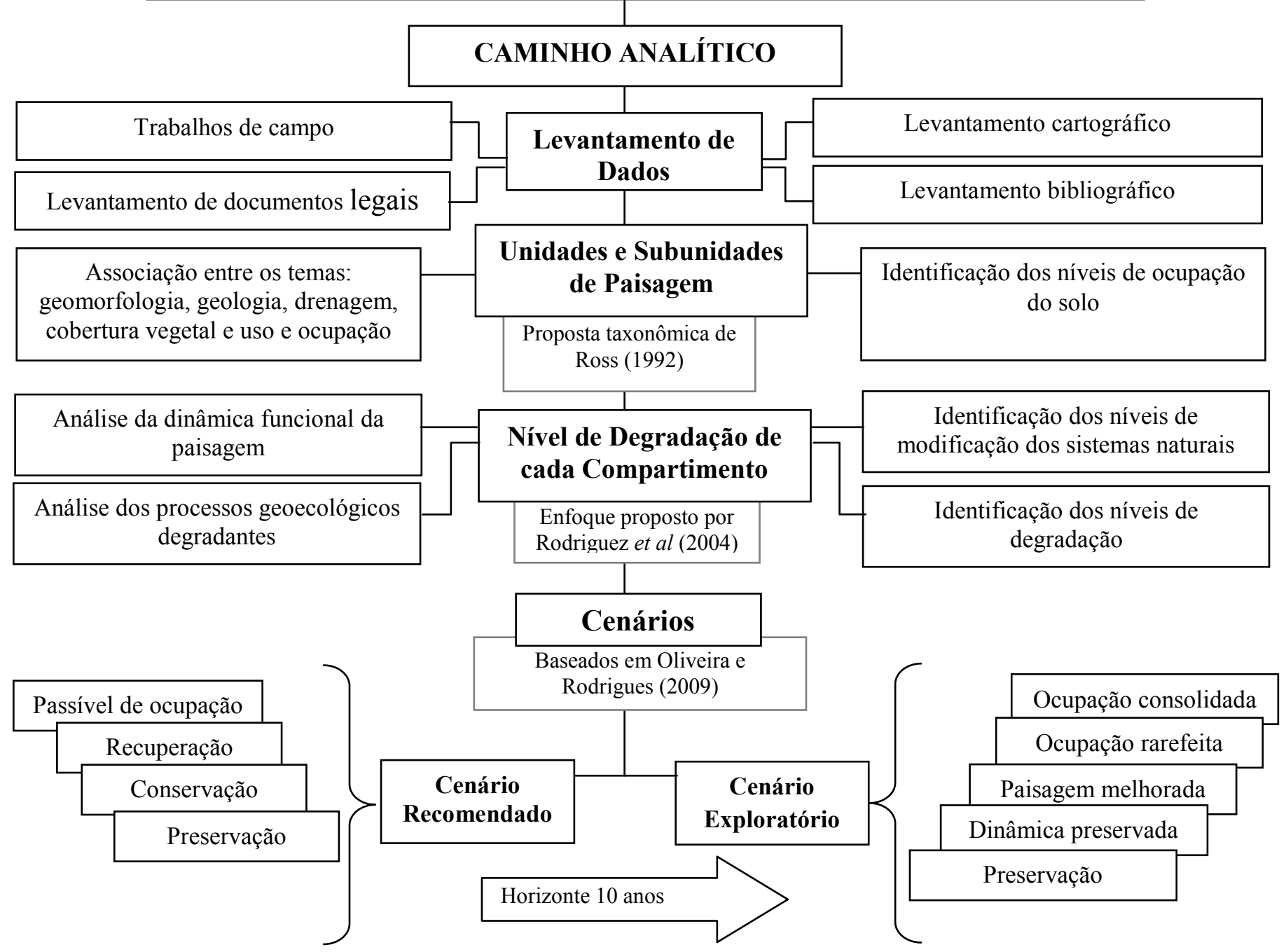

Fluxograma 01. Caminho analítico sobre a proposição de cenários para a Planície Costeira de Estância-SE.

Flowchart 01. Analytical perspective on the proposal of scenarios for the Coastal Plain of the Estância-SE

\section{RESULTADOS}

\subsection{Níveis de Degradaçáo das Unidades de Paisagem da Planície Costeira de Estância-SE}

A Planície Costeira do município de Estância possui uma área de 20.403,22 hectares e de acordo com SEPLAN/SRN (2004) encontra-se subdividida em quatro compartimentos geomorfológicos aqui considerados como unidades de paisagem, são elas: Planície Fluviomarinha, Terraço Fluviomarinho, Terraço Fluvial e Terraço Marinho (ver mapa de compartimentos geomorfológicos, Figura 2).

A partir desta classificação é que puderam ser compartimentadas as subunidades de paisagem mediante a associação das características geomorfológicas, com as geológicas, pedológicas, de declividade do terreno, bem como do uso e cobertura vegetal adotando-se como critériochave a identificação das formas de uso e ocupação do solo
(Figura 3) e análise dos processos de uso e níveis de ocupação do solo em cada unidade da Planície Costeira.

Nas unidades e subunidades da Planície Costeira de Estância possuidoras de diferenciadas caracterizaçóes biofísicas são encontrados diferentes tipos de uso que definem distintos níveis de ocupação relacionados a processos em sua maior parte de natureza degradante, os quais, ao interagirem com os processos da dinâmica natural dos ambientes biofísicos determinam variados níveis de degradação.

Nesse contexto, a caracterização biofísica e antrópica de setores homogêneos, a qual considera cada setor como uma unidade que apresenta um padrão semelhante de formas de relevo, solo, vegetação, alteração antrópica, discernível na paisagem e distinto em relação às unidades vizinhas, permite identificar a partir dos níveis de ocupação encontrados quatro unidades de paisagem e sete subunidades (Figura 04 e Quadro 03). 


\section{UNIDADES GEOMORFOLÓGICAS DA PLANÍCIE COSTEIRA DE ESTÂNCIA-SE}

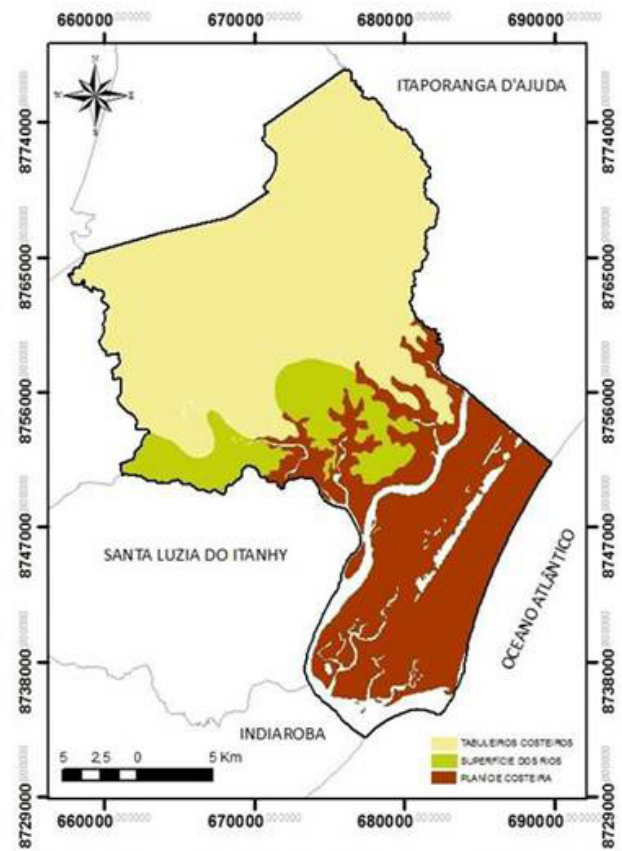

FONTE: ATLAS DIGITAL DOS MUNICIPIOS LITORÃNEOS DE SERGIPE, SRH, 2011. ORGANIZAÇÃO: ANIZZIA OLIVEIRA
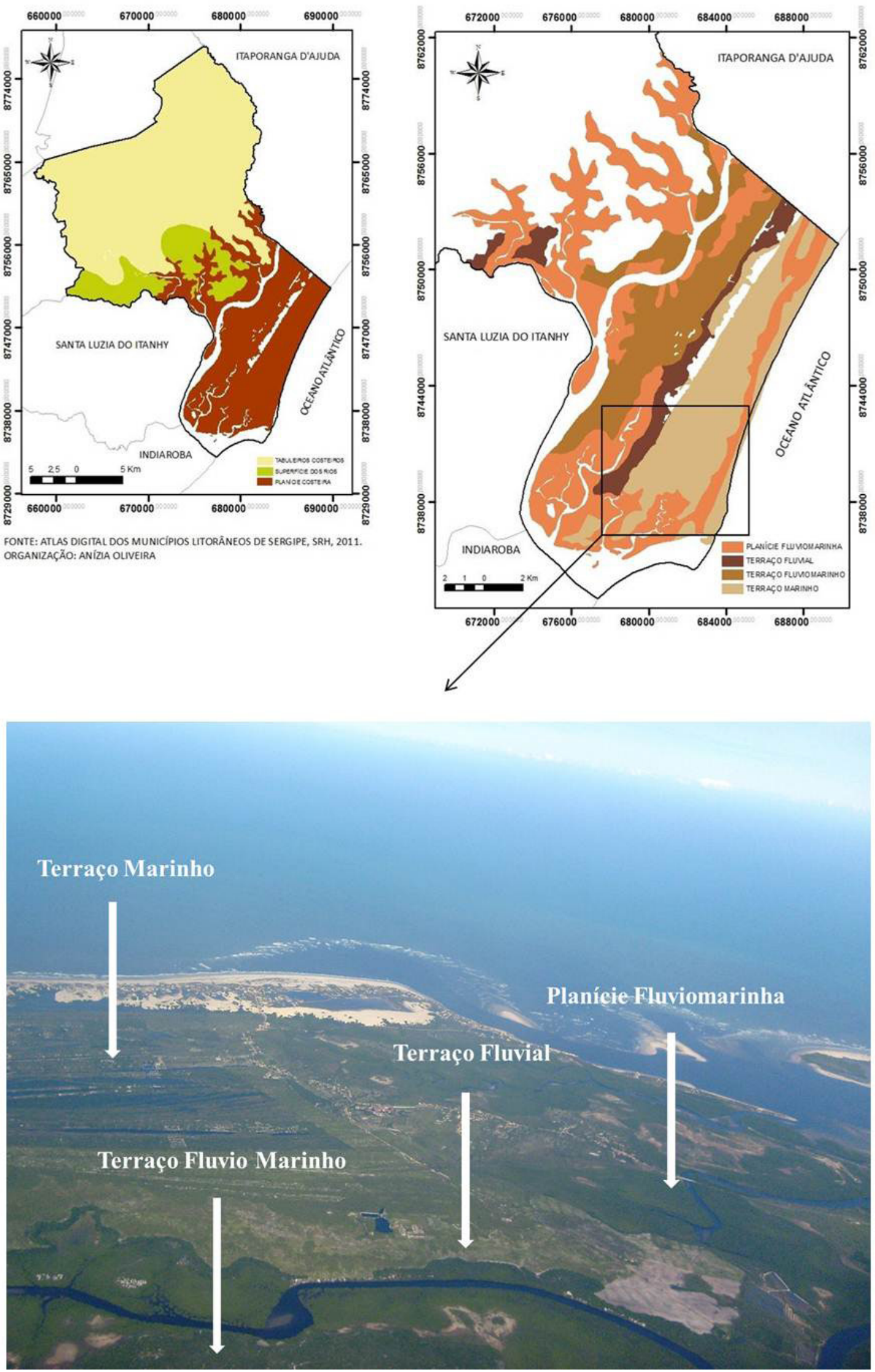

Figura 2. Unidades geomorfológicas da Planície Costeira de Estância-SE. Figure 2. Geomorphologic units of the Coastal Plain of the Estância-SE 


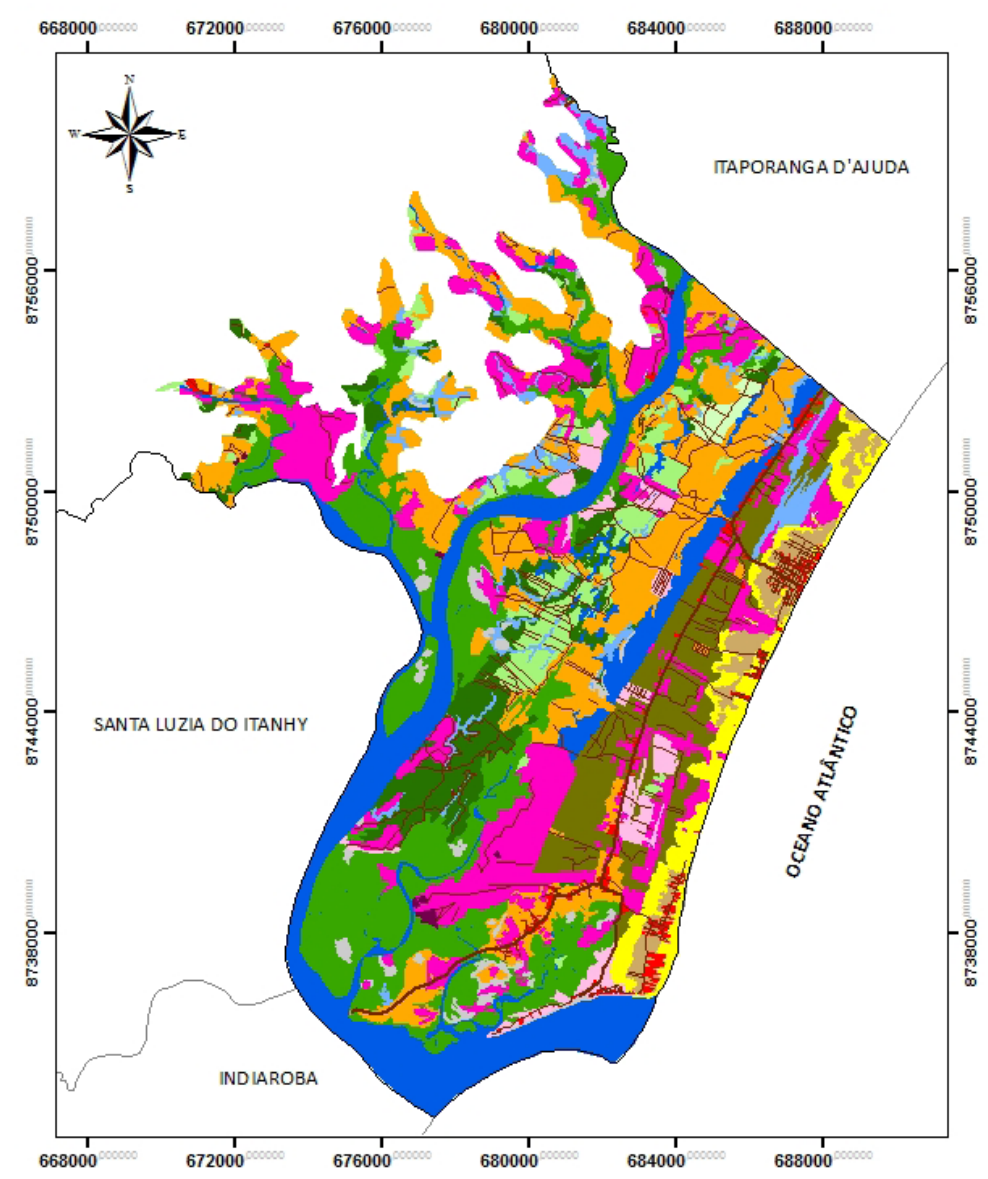

\section{USO E OCUPAÇÃO DO SOLO DA PLANÍCIE COSTEIRA DE ESTÂNCIA-SE}

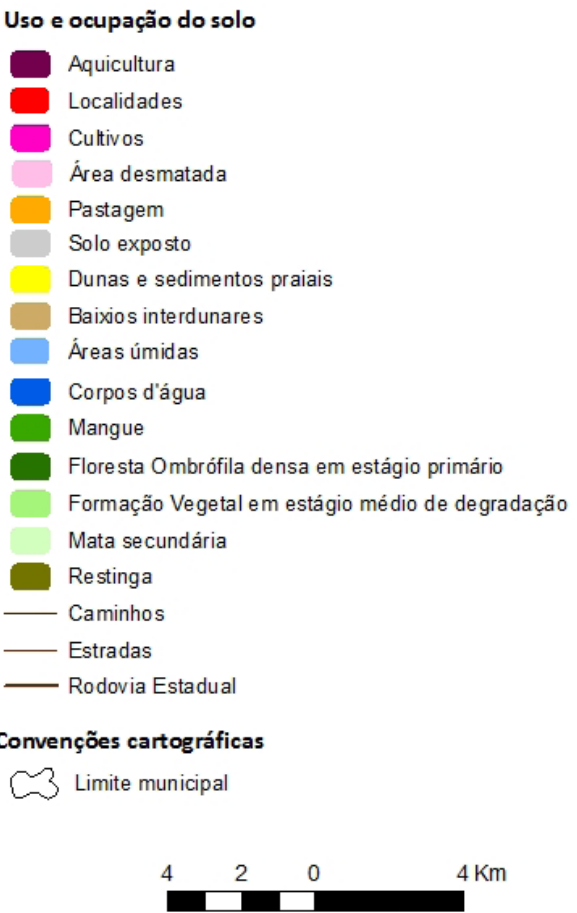

FONTE: BASE DIGITAL DOS MUNICÍPIOS LITORÂNEOS DE SERGIPE, 2003 ELABORAÇÃO: AN IZIAA OLIVEIRA

Figura 3. Uso e ocupação do solo da Planície Costeira de Estância-SE

Figure 3. Use and occupation of the coastal plain of the Estância-SE

\subsection{Planície Fluviomarinha}

A unidade de paisagem Planície Fluviomarinha abrange uma área de 8654,3 ha o que equivale a $42,41 \%$ da área total da Planície Costeira e subdivide-se em três compartimentos:

1. Planície Fluviomarinha com nível de ocupação baixo onde ocorrem superfícies aplainadas abaixo dos 10 metros compostas em sua maior parte por áreas de mangue;

2. Planície Fluviomarinha situada em faixa contínua paralela à linha de costa transitando em área de Terraço Marinho com dominância de relevo plano abaixo dos 10 metros e nível de ocupação muito baixo;

3. Planície Fluviomarinha com nível de ocupação alto em área de transição com zonas de Tabuleiros Costeiros a noroeste da Planície Costeira onde ocorrem relevos ondulados, dissecados em colunas e interflúvios tabulares e áreas com altitudes superiores até 40 metros.

O primeiro compartimento possui 3.738 hectares que representam 43,19\% da área total da Planície Fluviomarinha onde predominam superfícies aplainadas com altitudes abaixo dos 10 metros resultantes da acumulação fluvial e sujeitas a inundaçôes periódicas. A confluência do Rio Piauí e do Rio Fundo e o complexo estuarino Piauí/Fundo/Real definem a presença de muitos cursos d'água concentrados mais ao sul da planície.

No tocante à geologia há a dominância de depósitos marinhos e continentais costeiros datados do Quaternário. Em Sergipe são verificadas formaçôes de idade holocênica e pleistocênica. São encontrados depósitos datados do Holoceno recobrindo conjuntos mais antigos principalmente localizados em porções mais internas da Planície Costeira.

A alternância de períodos glaciais e interglaciais acompanhada de importantes flutuaçóes do nível do mar no Quaternário ocasionaram regressôes e transgressôes da linha de costa que, ao contribuírem com os processos de deposição e erosão, geraram feiçôes e ambientes dotados de grande dinamicidade no que se refere à constante capacidade de transformação existente.

Como componente da Planície Costeira, a Planície Fluviomarinha é marcada por estuários e manguezais que são ambientes costeiros com vida efêmera em constante transformação correspondendo a terrenos de sedimentos 


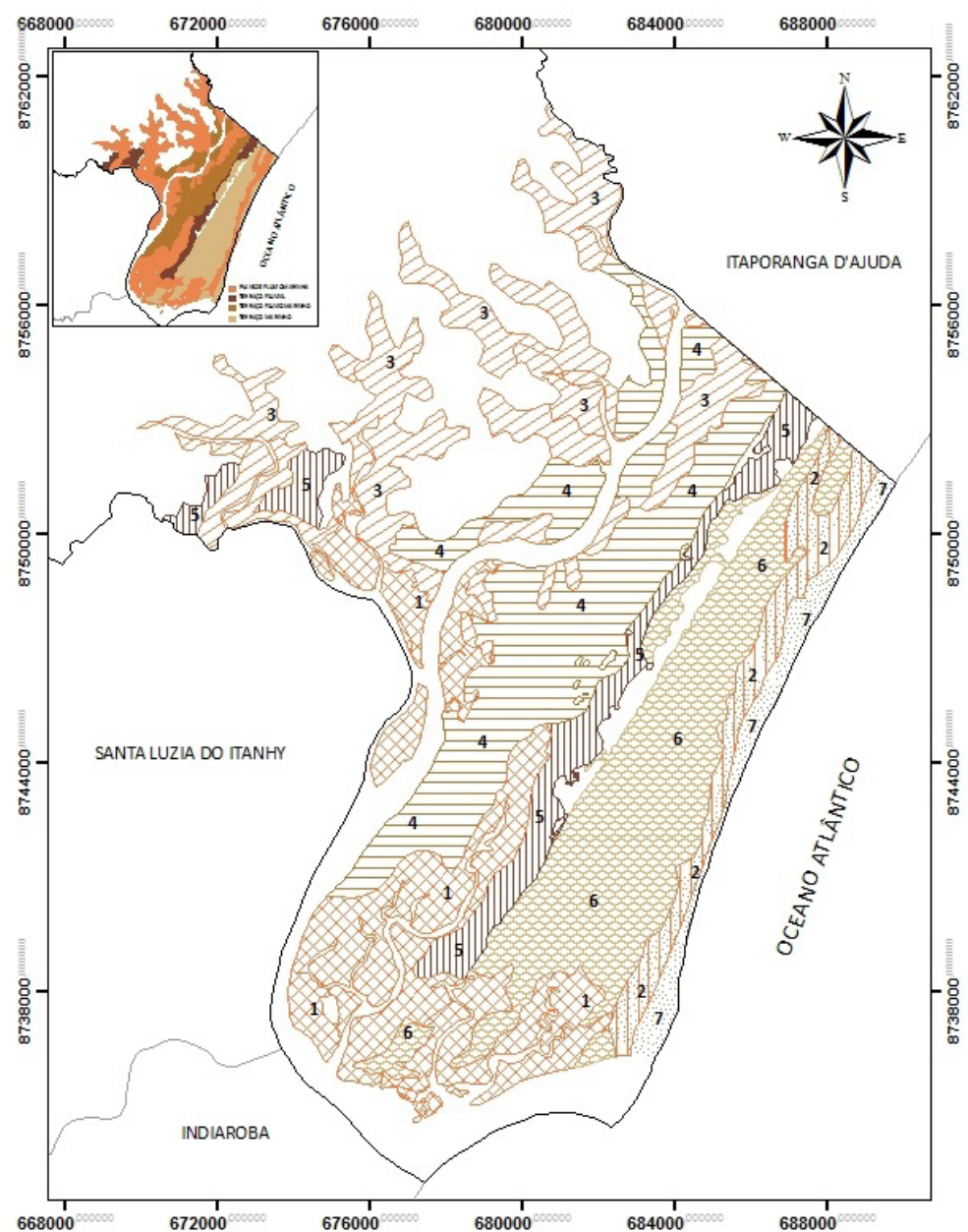

\section{UNIDADES E SUBUNIDADES DE PAISAGEM} DA PLANÍCIE COSTEIRA DE ESTÂNCIA-SE

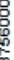

\section{PLANÍCIE FLUVIOMARINHA}

1 Com predominância de mangue - Nivel baixo de ocupação

1] 2 Em faixa contínua a linha de costa - Nivel muito baixo de ocupação

$3 \mathrm{Em}$ área de transição com os tabuleiros - Nível alto de ocu pação

TERRAÇO FLUVOMARINHO

4 Com nivel alto de ocupação

TERRAÇO FLUVAL

(IIII) 5 Comnivelmuito alto de ocupação

\section{TERRAÇO MARINHO}

6 Dominado por cordões litorâneos - Nivel médio de ocupação 7 Com predominância de superfícies praiais, dunas móveis e baixios interdunares - Nível médio de ocupação

Figura 4. Unidades e Subunidades da Planície Costeira de Estância-SE

Figure 4. Units and Subunits of the Coastal Plain of the Estância-SE

Quadro 3. Unidades e Subunidades de Paisagem da Planície Costeira de Estância-SE.

Table 3. Units and subunits and Environmental Status of the Coastal Plain of the Estância-SE

\section{Unidades de paisagem}

Planície Fluviomarinha

\section{Subunidades de paisagem}

(definidas a partir dos níveis de ocupaçáo)
PNTE: BASE DIGITAL DOS MUNICÍPIOS LITORÂNEOS DE SERGIPE, 2003. ELABORAÇ̃̃O: ANÍZIA OLIVEIRA

\begin{tabular}{l|l|l} 
& linha de costa & \\
\cline { 2 - 3 } & $\begin{array}{l}3 \text { Planície Fluviomarinha em área de transição } \\
\text { com os tabuleiros costeiros }\end{array}$ & Nível alto de ocupação 60.45\% \\
\hline Terraço Fluviomarinho & 4 Terraço Fluviomarinho & Nível alto de ocupação $60.30 \%$ \\
\hline \multirow{2}{*}{ Terraço Fluvial } & 5 Terraço Fluvial & Nível muito alto de ocupação 88.87\% \\
\hline \multirow{2}{*}{ Terraço Marinho } & $\begin{array}{l}6 \text { Terraço Marinho dominado por cordóes } \\
\text { litorâneos }\end{array}$ & Nível médio de ocupação $45.59 \%$ \\
\cline { 2 - 3 } & $\begin{array}{l}7 \text { Terraço marinho com predominância de } \\
\text { superfícies praiais, dunas móveis e baixios } \\
\text { interdunares }\end{array}$ & Nível médio de ocupação $42,83 \%$ \\
\hline
\end{tabular}


quaternários de aspecto transicional, influenciados, por um lado, pelos agentes continentais e, por outro, pelos agentes marinhos.

Prevalecem neste compartimento solos indiscriminados de mangue, ricos em matéria orgânica, mal drenados e de coloração escura, que apresentam altas concentraçóes de sais solúveis e textura argilo-siltosa. Há presença em menor quantidade de espodossolo no limite com o Terraço Flúvio Marinho, apresentando-se excessivamente drenado com baixo poder de armazenamento de água e de nutrientes devido à textura arenosa.

Predomina nesta subunidade, com $75,30 \%$ da área total, a vegetação de mangue caracterizada por grande homogeneidade fisionômica ocupando as bordas dos rios em espaços bem delimitados do estuário com maior expressividade na desembocadura onde aparecem manchas mais preservadas. De acordo com Carvalho e Fontes (2006) as três principais espécies encontradas em associação na área são Rhizophora mangle, Laguncularia racemosa e Avicennia germinas.

No que se refere aos tipos de uso e ocupação do solo há existência de aquicultura pontual ao sul da Planície Fluviomarinha em área de transição com o Terraço Fluvial. Já no limite com o Terraço Marinho aparecem manchas de áreas desmatadas com solo exposto e cultivos mais concentrados nas margens da Rodovia Estadual.

Isso faz configurar um baixo nível de ocupação com 20,13\% da área total. Todavia, com o avanço de infraestruturas exemplificadas pela construção de estradas e pontes e de empreendimentos imobiliários visando atender ao incremento do turismo na região há uma crescente tendência de ocupação nesta subunidade.

Esta subunidade da Planície Fluviomarinha apresenta uma dinâmica natural marcada por um regime de inundação controlado pela influência do ciclo das marés ao longo dos canais fluviais. Como marca desses ambientes, atuam processos de sedimentação e acumulação de matéria orgânica.

Sáo encontrados solos halomórficos nas áreas mais baixas. Relevos planos não costumam favorecer processos de dissecação. Porém, apesar do predomínio de baixas altitudes, nesta subunidade ocorrem solos com característica instável, sujeitos a inundações periódicas, fazendo com que a suscetibilidade à erosão passe a ser fator decisivo para a qualificação da dinâmica natural deste compartimento.

Apesar disso, mesmo havendo a presença de aquicultura pontual, manchas de solo exposto, cultivos concentrados nas margens da Rodovia Estadual SE-100, todos referindose a pontos de desmatamento que denotam a erradicação da vegetação nativa, há o predomínio da cobertura vegetal original. Os manguezais associados à presença de canais aparecem nesta subunidade em grandes manchas.

Sendo assim, esta subunidade de paisagem apresenta sistemas naturais parcialmente modificados, cujos processos degradantes que causam mudanças na estruturação da paisagem são identificados como de intensidade leve a moderada caracterizando um nível pouco degradado, ver Quadro 01 que mostra a associação entre as classes referentes à intensidade de modificação dos sistemas ambientais, aos níveis de ocupação e aos níveis de degradação, estes adaptados de Rodriguez et al (2004).
A segunda subunidade de paisagem Planície Fluviomarinha abrange uma faixa contínua paralela à linha de costa com 1036,3 hectares, cerca de $12 \%$ da área total, transitando em área de Terraço Marinho apresentando dominância de relevo suave, situado abaixo dos 10 metros.

Possui a mesma característica geológica do compartimento anterior com predomínio de depósitos marinhos e continentais costeiros. É comum neste compartimento a ocorrência de campos de dunas móveis e fixas intercaladas por baixios interdunares e áreas úmidas ocorrendo neossolos quartzarênicos em toda a sua extensão e formação vegetal de restinga com perfil arbóreo - arbustivo.

As dunas, os baixios e as áreas úmidas associadas à cobertura vegetal de restinga que se distribui em toda a extensão deste compartimento compóem o sistema biofísico da paisagem e totalizam $84,25 \%$ de área.

Em contrapartida, no tocante ao uso, um nível de ocupaçáo muito baixo com percentual de 15,75\% é encontrado em virtude da presença de cultivos pontuais e de algumas ocupaçóes de veraneio localizadas em zonas interdunares ao sul da Praia do Saco (Povoado Saco do Rio Real). São identificadas casas nas proximidades da faixa de praia que vem sendo atingidas pelo avanço do mar.

Nesta segunda subunidade da Planície Fluviomarinha ocorre uma dinâmica de inundação dominada pelas depressóes interdunares em que as áreas úmidas são periodicamente alagadas favorecendo condiçóes para o habitat de algumas espécies de animais.

Essa dinâmica natural é interrompida em muitos trechos a partir da existência pontual de ocupação por cultivos e habitaçóes principalmente em faixa próxima da linha de costa, quando ocorrem ambientes de dunas.

O nível de ocupação muito baixo marca um ambiente não modificado ou com modificação leve. Assim, seguindo as associaçóes presente no Quadro 01 que as classes referentes à intensidade de modificação dos sistemas ambientais, aos níveis de ocupação e aos níveis de degradação, estes adaptados de Rodriguez et al (2004), o nível de degradação identificado é sem ou muito pouco degradado.

A terceira subunidade, com 3880 ha e percentual de $44,83 \%$ da área total da Planície Fluviomarinha, refere-se às áreas próximas à transição com a zona de Tabuleiros Costeiros. Os Tabuleiros Costeiros são superfícies planas situadas na transição das Terras Altas com a Frente Marinha resultantes da erosão dos terrenos da Formação Barreiras sendo, muitas vezes, interrompidos pelos estuários dos rios que atingem o litoral e frequentemente utilizadas por plantações de coco da - baía e pastagem.

Nesta subunidade, ocorrem relevos ondulados, dissecados em colunas e interflúvios tabulares com altitudes entre 10 e 40 metros. Há a presença de muitos canais de primeira ordem e rios como o Rio Biriba e o Rio Fundo. São incluídas neste compartimento as áreas inundáveis que passam grande parte do ano alagadas por sofrerem influência fluvial.

As características geológicas favorece o predomínio de sedimentos marinhos e continentais costeiros, composto por material sedimentar formado por arenito, arenito conglomerático, argilito arenoso apresentando associação a noroeste com sedimentos do Grupo Barreiras em que afloram solos calcários pertencentes à Formação Cotinguiba (Cretáceo Superior) no fundo de vales dos tabuleiros dissecados. 
O tipo de solo com maior ocorrência é o argissolo vermelho - amarelo localizado na região de contato entre os Tabuleiros Costeiros (Grupo Barreiras) com a Planície Costeira. Também são encontrados solos halomórficos nas áreas mais baixas onde domina a influência dos cursos dos rios.

Os manguezais associados à presença de canais aparecem nesta subunidade em pequenas manchas. São raras também as áreas com formaçôes pioneiras de Floresta Ombrófila dotadas de espécies arbóreas de grande porte.

Pode-se dizer que esta situação decorre das formas de uso do solo marcadas pela intensa utilização agrícola, pela presença de construçôes, loteamentos e habitaçóes populares e de áreas desmatadas, no geral, destinadas às pastagens.

Os cultivos são, em sua maioria, de caráter permanente e estão relacionados à cocoicultura ocorrendo em vastas áreas da planície e em superfícies de inundação sazonal, principalmente nas margens dos corpos d'água e áreas úmidas adjacentes.

As áreas desmatadas são áreas onde a vegetação, seja ela de mangue, de restinga ou de floresta, encontra-se suprimida apresentando pastagens extensivas e trechos com cultivos em seu entorno sendo comumente tomadas por estradas e caminhos.

As moradias não são atendidas por serviço de infraestrutura básica. Há necessidade de melhorias nas condições habitacionais pela implantação de serviços de água, energia e esgotamento sanitário, bem como de equipamentos e áreas de lazer de uma forma que prioritariamente seja compatível com a qualidade ambiental da área.

Todos estes fatores possibilitam a identificação de um nível alto de ocupação com usos antrópicos que abrangem 60,45\% deste compartimento da Planície Fluviomarinha.

Assim como acontece no primeiro compartimento da Planície Fluviomarinha, uma dinâmica de inundaçáo gera processos de sedimentação e acumulação de matéria orgânica ao longo dos cursos fluviais. Esta subunidade é constituída por áreas com altitudes que chegam a 40 metros na região de contato entre os Tabuleiros Costeiros (Grupo Barreiras) com a Planície Costeira, sendo o argissolo vermelho - amarelo o tipo de solo com maior ocorrência.

Sabe-se que relevos ondulados, a depender da influência da porosidade e permeabilidade do solo, apresentam uma maior suscetibilidade à erosão. A utilização agrícola nas superfícies de inundação sazonal, a presença de vastas áreas desmatadas destinadas a pastagens principalmente em margens dos corpos d'água e a ocupação por casas construídas nas proximidades de rios, provenientes de formas de desmatamento indiscriminado da vegetação natural de mangue, acabam acarretando problemas como erosão do solo e das margens dos canais, alteração da drenagem, perda de nutrientes do solo e poluição do solo e da água.

Esta situação promove declínio parcial da estrutura espacial e funcional dos sistemas e eliminação paulatina das funçóes ecológicas fazendo predominar ambientes fortemente modificados.

\subsection{Terraço Fluviomarinho}

A unidade Terraço Fluviomarinho representa uma área de 4304,8 ha, 21,09\% da Planície Costeira, e situa- se entre a Planície Fluviomarinha e o Terraço Fluvial. Tal compartimento também apresenta nível alto de antropização com $60,30 \%$ da área tomada por ocupação humana.

Nesta unidade há o predomínio de relevo suave com altitudes menores que 10 metros apenas havendo valores superiores, mas não ultrapassando os 30 metros, na área de transição com o Terraço Fluvial. Esta unidade apresenta sedimentos marinhos e continentais costeiros, não consolidados, de natureza e granulometria variadas com dominância de areia, argila e sedimentos eólicos.

Predomina um tipo de solo, o halomórfico (indiscriminado de mangue) nas áreas de transição com a Planície Fluviomarinha, apesar de grande ocorrência de espodossolo.

Esta unidade é recortada pelo Rio Fundo e canais distributários. Por fazer limite com a Planície Fluviomarinha e por abranger longo trecho marginando os cursos fluviais, apresenta porçôes de vegetação de mangue e algumas manchas mais ao sul de Floresta Ombrófila densa que, ora permanecem em seu estado mais primário, ora indicam níveis baixos de antropização. Sáo pequenas porçóes de cobertura vegetal original que resistem aos processos de uso e ocupação do solo.

Quanto às formas de uso e ocupação, neste compartimento existem muitos terrenos preenchidos por cultivos, áreas desmatadas com solo em exposição, além de pastagens, na sua maioria de caráter extensivo. Devido à ocorrência de extensas áreas destinadas à pecuária (cerca de 25\%) e cultivos principalmente de Cocos nucifera são comuns manchas de vegetação em estado médio e avançado de degradação.

Esta unidade da Planície Costeira é marcada pelo Rio Fundo e por canais distributários cujas presenças dão destaque a paisagem deste compartimento. No que se refere à dinâmica natural, o relevo plano e o regime de oscilação das marés promovem a acumulaçáo de sedimentos arenoargilosos finos. Inundaçóes periódicas favorecem condições adequadas para a geração de habitats para animais, influindo diretamente na reprodução de espécies da avifauna.

Entretanto, a dinâmica natural vem sendo afetada por processos degradantes. A ocorrência de áreas com pastagens e cultivos em quase toda extensão alteram a paisagem natural, sobretudo, pelo desmatamento das margens do Rio Fundo.

A vegetação original de mangue vem sendo substituída por uma cobertura vegetal esparsa o que acarreta um processo erosivo e poluição do solo e da água e a degradação da qualidade dos mananciais.

Diante disso, o Terraço Fluviomarinho é identificado como um nível alto de ocupação e enquadra-se como unidade de paisagem degradada em que a perda parcial da estrutura espacial e funcional deste compartimento dá lugar à desestruturação da integridade biofísica dos ambientes naturais.

\subsection{Terraço Fluvial}

A outra unidade componente da Planície Costeira é a unidade Terraço Fluvial. Com 1520,72 ha e um percentual de 7,45\% configura-se como a menor unidade da Planície Costeira, contudo, nela aparecem as maiores altitudes predominando relevo entre 20 e 30 metros em quase toda 
margem das lagoas Grande e Funda chegando a 50 metros a oeste já em porção mais interna, no limite com a Planície Fluviomarinha e as superfícies dissecadas dos rios.

Esta unidade forma uma faixa contínua situada entre o Terraço Fluviomarinho e o Terraço Marinho onde são encontrados depósitos marinhos e continentais costeiros e sedimentos não consolidados compostos por areia, argila, sedimento eólico. Constitui-se por depósitos aluvionares mais antigos e em nível mais alto do que o atual conformandose como relevo-testemunho de um período de evoluçáo da Planície Costeira relacionado a antigas planícies de inundação.

Quanto aos tipos de solos destacam-se os neossolos quartzarênicos e o espodossolo, sendo que ao sul, nas proximidades da desembocadura, e a oeste há pequena presença de solos halomórficos, havendo também pequena mancha de argissolo vermelho-amarelo.

A cobertura vegetal original praticamente inexiste nesta unidade da Planície Costeira, apenas algumas poucas manchas de formação arbóreo-arbustiva de restinga compondo setores de paleodunas fixas em relevo suave ondulado, ondulado a forte ondulado.

Tomada por áreas compostas em sua maior parte por pastagens e cultivos $(86,55 \%$ da área total), esta unidade é preenchida por estradas e caminhos em toda a sua extensão. Destaque para grande área com cultivo de coco ao sul. No limite inferior, em setor de transição com a Planície Fluviomarinha, aparecem viveiros, sobretudo, relacionados à produção de camarão.

Assim, a ocupação por cultivos, pelas fazendas de camarão e pela presença de atividade pecuária de natureza extensiva perfazem uma área de $88.87 \%$ caracterizando o Terraço Fluvial como unidade com nível muito alto de ocupação.

Nesta unidade de paisagem os fatores relacionados ao uso e ocupação do solo são os que interferem na dinâmica natural dos agentes continentais responsáveis pela estrutura e funcionamento desta unidade.

Tais fatores estão representados pelas pastagens e cultivos presentes em toda a extensão. $\mathrm{O}$ alto grau de antropização decorre de impactos ambientais associados à ocupação de cultivos e pastagens e de extraçáo de areia irregular em áreas de paleodunas, caracterizando comumente a perda irrecuperável de ambientes com importante potencial biológico e paisagístico.

O preenchimento de grandes áreas por plantaçóes de coco (Cocus nucifera) através do desmatamento altera as propriedades do solo aumentando a exposição do terreno ao poder da erosão. Também a presença de atividade pecuária de natureza extensiva favorece o aparecimento de processos erosivos, já que a substituição da cobertura nativa por cultivos anuais torna os solos mais susceptíveis à erosão laminar.

Em se tratando do nível de degradação, encontra-se um nível muito degradado.

\subsection{Terraço Marinho}

A paisagem costeira de Sergipe é marcada por terraços marinhos que, de acordo com Fontes (2007), são, em geral, antigos depósitos de origem marinha, com formas tabulares e topos planos, geralmente com cotas altimétricas inferiores a cinco metros, que foram soldados à Planície Costeira.

A unidade de paisagem Terraço Marinho que com 5.923,4 ha representa 29,03\% da área total da Planície Costeira foi subdividida em dois compartimentos:

1. Terraço Marinho com nível de ocupação médio formado por superfícies planas dominadas por baixios alagados e cordóes litorâneos regressivos dispostos de forma paralela à linha de costa;

2. Terraço Marinho com nível médio de ocupação tendo o predomínio de superfícies praiais, de antedunas, de dunas móveis e baixios interdunares.

A primeira subunidade é a do Terraço Marinho marcado por superfícies aplainadas dominadas por áreas de restinga, baixios inundáveis e cordóes litorâneos regressivos paralelos à linha de costa.

Este compartimento apresenta 4174 ha e abrange $70,46 \%$ da unidade Terraço Marinho. Possui grande trecho que faz limite com as Lagoas Funda e Grande. São encontradas, além das lagoas permanentes, muitas zonas úmidas que sofrem influência dos períodos de maior pluviosidade.

Quase metade da área, mais precisamente 49,70\%, é composta por vegetação de restinga que se caracteriza como associação perenifólia, pouco densa, com variadas espécies arbóreo-arbustivas com destaque para o cajueiro (Anacardium occidentale), murici (Byrsonima sp.), mangabeira (Hancornia speciosa) e se distribui de forma esparsa em muitos trechos, sendo entremeada por cordóes litorâneos em forma de faixas de solo arenoso esbranquiçado que se expóe quando da ausência de cobertura vegetal, intercalados por baixios que alagam no período mais chuvoso.

De acordo com Neto et al. (2004), cordóes litorâneos são barreiras arenosas com feiçóes alongadas paralelas à linha de costa, totalmente isolados do continente (ilhas barreiras) ou soldados a ele por uma das extremidades (pontais arenosos) a linha de costa. Essas feiçóes podem isolar lagunas costeiras, sedimentadas ou náo por canais que permitem a circulaçáo da água no ciclo das marés entre a laguna e o mar aberto.

Em Sergipe, tais depósitos arenosos são considerados como areias litorâneas regressivas e apresentam-se descontínuos em muitos setores pela migração dos campos de dunas ou por algum mecanismo de ocupaçáo antrópica.

Nesta subunidade ocorrem sedimentos inconsolidados, com variaçẫo granulométrica e material sedimentar arenoargiloso e de sedimento eólico. Predominam espodossolos tendo também a presença de neossolos quartzarênicos ocupando margens das referidas lagoas.

Quanto ao uso e ocupação do solo, há cultivos permanentes de coco-da-baía presentes de forma bem distribuída e associados muitas vezes às pastagens e a prática de agricultura familiar de subsistência em sítios e chácaras composta, em sua maior parte, por cultivos temporários de frutíferas somando no total $33,48 \%$ da área. Presença também de casas e estabelecimentos comerciais em toda a extensão da Rodovia Estadual e margens da Lagoa Grande.

Destaques para os povoados Riboleirinha, Porto do Mato e Saco do Rio Real, localidades do município de Estância onde aparecem as áreas de maior adensamento, sendo encontradas nas suas imediaçóes áreas desmatadas com solo exposto, caminhos e estradas completando a paisagem. 
Os povoados Riboleirinha e Porto do Mato, localizados em porções mais interiores do Terraço Marinho são formados por habitaçóes populares. Na Praia do Saco o processo de ocupação é antigo e remete ao núcleo inicial de povoamento. Compóe terrenos nas proximidades da linha de costa e é onde se localizam as construçóes de alto padrão com proprietários detentores das rendas mais altas. As casas de veraneio, em sua maioria, ocupam de forma irregular áreas próximas ou sobre os campos de dunas móveis.

Em praticamente todas as localidades, é notória a deficiência na oferta de saneamento básico. Problemas com o esgotamento sanitário, abastecimento de água, coleta dos resíduos sólidos são frequentes. A coleta de lixo não é eficiente, os destinos mais comuns dados aos resíduos são a queima e o lançamento em terrenos baldios ou em vias públicas.

Muitos residentes captam água de poços semiartesianos, uma vez que, o abastecimento por rede geral ainda não abrange toda a população dos povoados. A água proveniente da perfuraçáo de poços náo recebe nenhum tratamento e apresenta alta concentraçáo de ferro possuindo cor e odor característicos.

Os usos e as formas de ocupaçáo encontrados neste compartimento do Terraço Marinho totalizam 45.59\% da área enquadrando-o no nível médio de ocupação.

Esta subunidade de paisagem dominada por cordōes litorâneos com nível de ocupação médio apresenta cultivos com predomínio de coqueirais de forma bem distribuída evidenciando o processo agrícola na região. A populaçáo dos povoados, principalmente do Porto do Mato e Saco, em sua maioria, sofre com a ausência de oferta de rede de esgoto, água e pavimentação evidenciando problemas ambientais como a contaminação do solo e dos lençóis freáticos por fossas rudimentares e resíduos sólidos e contaminação das águas superficiais pela emissão de efluentes nos canais.

Quanto ao nível de degradação, as formas de uso e ocupação existentes, cujas interferências provocam uma desestruturação da paisagem, fazem caracterizar sistemas naturais medianamente modificados a modificados identificados pela perda parcial da estrutura espacial e funcional, apesar de ainda conservarem a capacidade de recuperação ao estado original. Ocorre um nível médio de degradação com predomínio de processos pouco degradantes a degradantes.

A segunda subunidade do Terraço Marinho possui 1749,4 ha e 29,53\% em relação à área total sendo caracterizada pela presença de dunas móveis e em processo de fixaçáo e por superfícies com formações praiais e de antedunas distribuídas ao longo da linha de costa.

Em Sergipe, sobre os terraços marinhos holocênicos da Planície Costeira encontram-se as geraçóes de dunas recentes divididas em conjuntos mais internos, já fixas e do tipo parabólico e, bordejando o litoral, do tipo barcanas (Bittencourt et al. 1982). São constituídas de sedimentos arenosos, bem selecionados. As dunas parabólicas estão fixadas pela vegetaçấo e ocorrem na parte mais interna dos terraços marinhos holocênicos.

Nesta subunidade da Planície Costeira de Estância encontram-se tipos de relevo suave ondulado, ondulado e forte ondulado. Há relevo plano com cotas altimétricas menores que 10 metros, marcado por praias que acompanham a orla marítima. Valores acima de 10 metros aparecem em porçôes de dunas semifixas com altitude não superior aos 20 metros. No caso das dunas estabilizadas, estas ocorrem intercaladas com as dunas móveis nas proximidades da praia ou mais recuadas em direção ao continente.

Em toda a extensão desta subunidade há presença de zonas interdunares, baixios periodicamente alagados dependentes das condiçôes de pluviosidade.

Depósitos marinhos e continentais costeiros, compostos por sedimentos inconsolidados e bem selecionados são características geológicas desta subunidade. Há presença de neossolos quartzarênicos ocupando de forma contínua a zona praial. Este tipo de solo apresenta cor clara e esbranquiçada, constituído basicamente de quartzo, muito profundo, excessivamente drenados e de baixa fertilidade natural.

Nos ambientes de praia e de dunas embrionárias a cobertura vegetal inclui espécies psamófilas como a salsa-dapraia (Ipomoea pescaprae) em áreas de associação entre praias e antedunas. Em setores de dunas móveis, há o predomínio de vegetaçáo perenifólia de restinga com perfil arbustivo, em setores de dunas fixas ou em fase de estabilização encontra-se vegetação de restinga arbóreo-arbustiva, estas sofrem processos pedogenéticos que favorecem a fixaçáo de recobrimento vegetal em sua superfície.

No tocante ao uso há uma densidade média de habitação principalmente nas porções nordeste (Abaís) e sul (Povoado Saco do Rio Real). Na Praia do Abaís cresce o número de imóveis destinados à segunda residência. São comuns dunas e zonas interdunares alteradas $(32,11 \%$ da área), pois são alvos da especulação imobiliária pelo avanço da ocupação de veraneio, crescente expansão de arruamentos e loteamentos.

$\mathrm{Na}$ Praia do Saco muitos lotes chamam atençáo pelo tamanho da propriedade e por se localizarem em áreas de dunas. A inexistência de um campo dunar pleno acontece também pela barreira de casas, tráfego motorizado sobre praia e dunas, e turismo desordenado.

Destacam-se como grande ameaça aos sistemas dunares instalaçóes comerciais situadas à beira-mar. $\mathrm{Na}$ área mais visitada por banhistas presenciam- se bares voltados para o lazer, porém com precárias instalaçóes.

Práticas de recreação, lazer, turismo pontual e esporádico nas áreas de dunas móveis sáo comuns. Aliado a isso, uma dinâmica imobiliária impulsionada pelo avanço da segunda residência e infraestrutura de médio porte (iluminação pública, torres de telefonia, ruas asfaltadas) vem se manifestando de forma crescente. Toda esta situação aliada à presença de alguns cultivos expóe para esta subunidade um nível médio de 42,83\% de ocupação.

Atuam, atrelados à dinâmica natural, processos de acresção e acumulação de sedimentos, colonização de espécies psamófilas nos setores de antedunas, progradação dos sedimentos favorecendo, com isso, o desenvolvimento e evolução da morfologia dunar. Os baixios interdunares, ambientes integrados aos sistemas dunares, interrompem a continuidade das feiçôes e são dependentes do regime pluviométrico alagando-se periodicamente quando ocorre a subida do lençol freático.

Contudo, o ritmo e a densidade de ocupação nas Praias do Saco e Abaís impóem limitaçōes à dinâmica natural dos sistemas biofísicos presentes neste compartimento da Planície Costeira. 
Fatores de ameaças ao sistema dunar e às áreas de baixios interdunares estão representados pela ocupação por construçóes e infraestrutura humana principalmente nas áreas de antedunas; pelo turismo pontual e esporádico nas áreas de dunas móveis; por uma dinâmica imobiliária impulsionada pelo avanço da ocupação de veraneio e por manchas de cultivos e áreas desmatadas.

Esta subunidade é alvo da especulação imobiliária, do avanço da ocupação de veraneio, e da crescente expansão de loteamentos. A infra-estrutura turística é considerada como um indicador que vem impondo limitaçôes à dinâmica natural dos ambientes dunares do Litoral Sul de Sergipe, uma vez que, a intensificação das atividades turísticas vem promovendo desmonte de dunas móveis para loteamentos, residências secundárias e hotéis. $\mathrm{O}$ interesse pelo desenvolvimento do turismo no Litoral de Sergipe parte principalmente de empresas hoteleiras que visam o estabelecimento de grandes complexos de hotéis (resorts).

Tais fatores geram graves problemas ambientais, a saber: acúmulo de resíduos sólidos a sotavento das dunas, remobilização de material nos campos de dunas decorrentes do desmatamento, deposição de esgotos "in natura" em corpos d'água, bloqueio da alimentação no sentido praiaduna e consequente erosão na zona de praia em virtude do déficit de sedimentos por conta das barreiras antrópicas, comprometimento dos processos de recomposição dunar e perda significativa de sua capacidade evolutiva, etc.

São pressóes que indicam fortes mudanças na estruturação dos sistemas naturais. A paisagem medianamente modificada a modificada ainda conserva a capacidade de recuperaçáo, porém apresenta um nível de degradaçáo de pouco degradado a degradado. A estabilidade natural modifica-se progressivamente, como consequência, ocorre uma perda parcial da estrutura espacial e funcional com eliminação paulatina das funçóes ecológicas.

A compartimentação da Planície Costeira do município de Estância em unidades e subunidades de paisagem, por considerar a associação entre as características geomorfológicas, geológicas, pedológicas, bem como da vegetaçáo, seus componentes geoecológicos e as descontinuidades espaciais resultantes das interferências de ordem antrópica possibilita um melhor entendimento da configuração da paisagem em termos de elementos e fatores envolvidos na sua estruturação.

\section{CENÁRIO RECOMENDADO}

A identificação dos níveis de ocupação de cada unidade e subunidade de paisagem da Planície Costeira de Estância e a análise dos processos degradantes em cada compartimento permitiu o desenvolvimento de cenários como alternativa de uso para os diversos problemas socioambientais identificados na área de estudo.

Com subsídio ao ordenamento territorial que visa à compatibilização das necessidades do homem, relativas à ocupação e ao uso do solo, com a capacidade de suporte dos ambientes naturais este trabalho objetiva a proposição de um conjunto de açôes, aqui enquadradas como classes componentes da proposta de cenário recomendado (Figura 05).
Tais classes estão elencadas a seguir:

\section{Classe de Preservaçáo}

Abrange a manutenção da dinâmica e funçôes naturais com atividades compatíveis com estratégias de açóes preventivas em conformidade com o determinado na legislação ambiental.

As áreas propostas para esta classe envolvem na unidade Planície Fluviomarinha todas as áreas de mangue localizadas nas margens dos cursos fluviais. Esta classe também engloba assim como as áreas de dunas, nascentes, áreas de mata ciliares ainda não afetadas pela ocupação humana.

Dentro da unidade Terraço Fluviomarinho estão incluídas nesta classe a preservação das margens do Rio Fundo e áreas de manguezal a fim de evitar a degradação e assoreamento do sistema fluvial.

No Terraço Fluvial inserem-se as áreas compostas pelas margens das lagoas Funda e Grande buscando, dentre os fatores relevantes, a proteção da diversidade das espécies de animais e vegetais.

No Terraço Marinho enquadra-se a vegetação original de restinga quando localizada, de acordo com o disposto na legislação federal (Resolução CONAMA 303, de 20/03/02), em faixa mínima de trezentos metros, medidos a partir da linha de preamar máxima ou em qualquer localização ou extensão, quando recoberta por vegetação com função fixadora de dunas ou estabilizadora de mangues. Também constituem essa classe as lagoas permanentes e de regime estacional, além dos sistemas de dunas embrionárias, móveis e em processo de fixação.

Destaque para a necessidade urgente de açóes que visem conter o problema da ocupaçấo indevida por casas de veraneio nas proximidades da faixa de praia em áreas de antedunas, tendo em vista que, tais tipos de intervençóes na dinâmica natural destes ambientes alimentam os efeitos da erosão marinha.

\section{Classe de Conservaçáo}

Classe onde o objetivo maior é a conservação, podendo haver formas restritas de ocupaçáo desde que por meio de controle rigoroso e de maneira a respeitar a capacidade de suporte dos ambientes naturais. As formas de uso e ocupação devem ser compatíveis com a conservação da qualidade ambiental.

As porçôes pertencentes a esta classe compreendem na unidade Planície Fluviomarinha as áreas úmidas sujeitas à inundação periódica e os baixios interdunres. São áreas compostas em sua maioria por terrenos inundáveis localizados principalmente nas proximidades dos canais fluviais. Sáo áreas importantes para a manutenção das áreas de preservação permanente. Estas áreas também estão presentes na unidade Terraço Fluviomarinho sendo importantes para a conservaçáo do equilíbrio dos ecossistemas componentes da paisagem.

No Terraço Fluvial recomenda-se o controle do uso agrícola em áreas mais acidentadas a fim de conservar o solo contra os efeitos da erosão. Em áreas planas as restrições quanto à ocupação são menores, porém nas áreas mais elevadas, por conta da instabilidade do solo, deve-se coibir instalaçôes humanas a fim de evitar riscos à ocupação. Deve- 


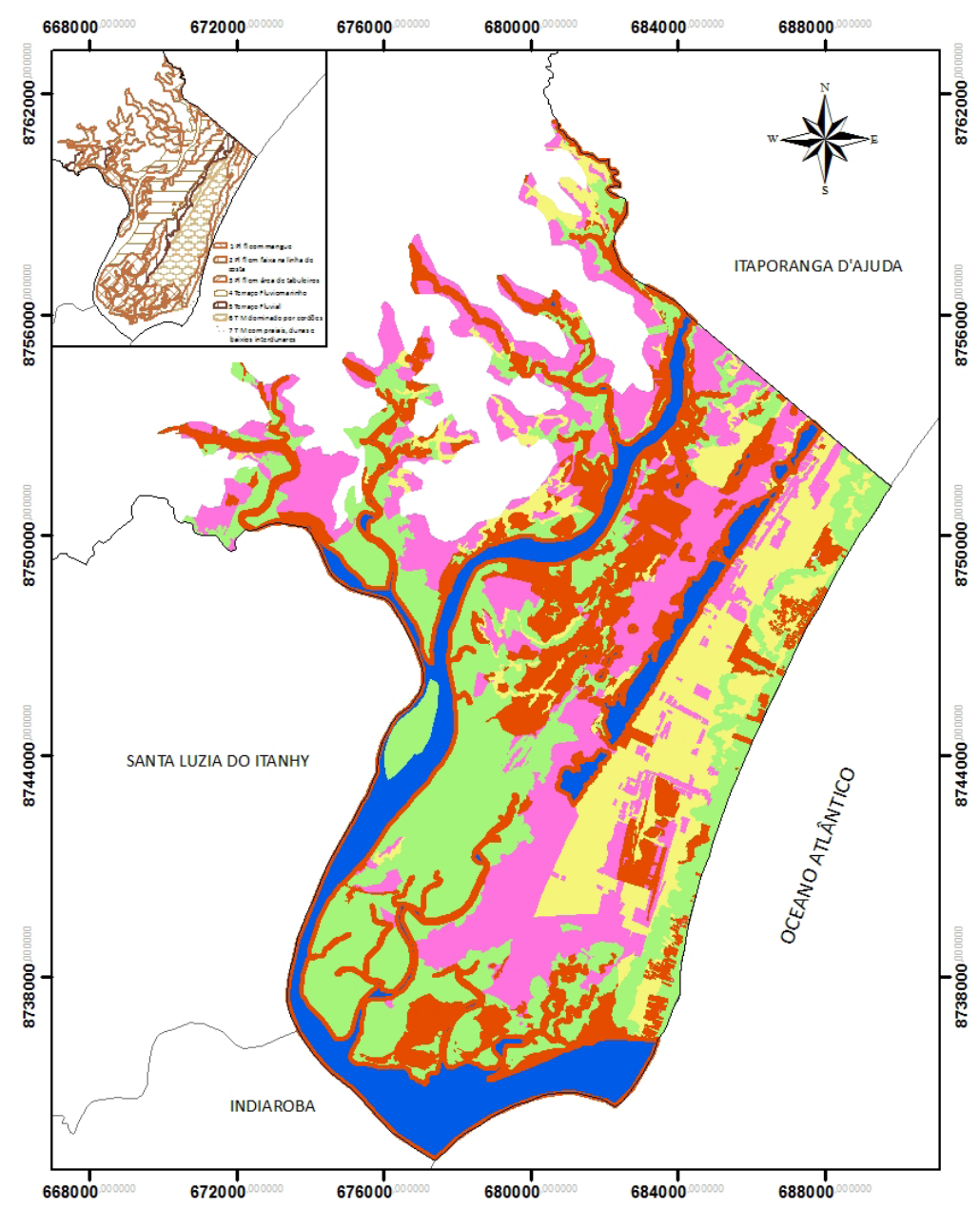

\section{CENÁRIO RECOMENDADO PLANÍCIE COSTEIRA DE ESTÂNCIA-SE}

Classes propostas

Preservação

Conservação

Recuperação

Passível de ocupação

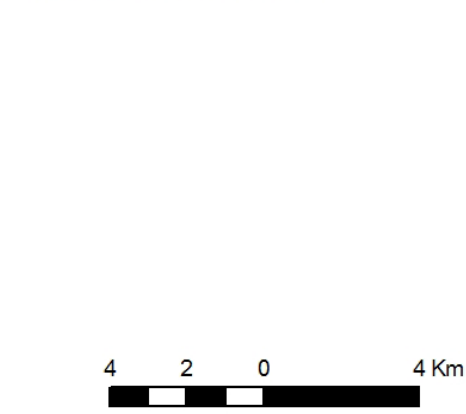

FONTE: BASE DIGITAL DOS MUNICÍPIOS LITORÂNEOS DE SERGIPE, 2003. ELABORAÇÃO: ANÍZIA OLIVEIRA

Figura 5. Cenário recomendado para a Planície Costeira de Estância-SE.

Figure 5. Recommended scenario for the Coastal Plain of the Estância-SE

se assim buscar a compatibilização da atividade agrícola, considerando critérios adequados de uso e conservação com base nas reais vocaçôes do território.

No Terraço Marinho as áreas úmidas aparecem em forma de baixios interdunares. Há existência de corpos d'água e superfícies inundáveis localizadas entre cordōes em área de restinga onde deve haver controle da qualidade da água para conservar as condiçóes de vida da fauna e flora locais. Recomenda-se não apenas a restrição, mas sim a proibição de construção de habitaçóes nos terrenos naturalmente encharcados, bem como a novas ocupaçóes e parcelamentos em áreas de alto valor ecológico para a conservação destes ambientes.

\section{Classe de Recuperação}

Classe em que se recomenda a recuperação das áreas onde ocorrem manchas de áreas desmatadas, de solo exposto e cultivos, devendo por isso haver recuperação da vegetação original, sobretudo nas margens dos rios da Planície Fluviomarinha.

Principalmente na unidade Terraço Fluvial que abrange áreas atualmente ocupadas por pastagens, por localidades, cultivos recomenda-se a recuperação da vegetação nativa das áreas desmatadas. Também a proibição de extração irregular de areias e construção de moradias nas margens dos cursos d'água visando à recuperação das porções de terreno degradadas.

Recomenda-se a recuperação da mata ciliar dos canais distributários, das áreas compostas por vegetação em estágio médio e avançado de degradação encontradas no Terraço Fluviomarinho e da vegetação original de restinga pertencente ao Terraço Marinho.

Nas áreas formadas por superfícies inundáveis deve-se investir na implantação de infraestrutura viária e de drenagem capazes de suportar determinado grau de adensamento, sendo que os terrenos, ou parte deles, mais encharcados não poderão ser ocupados com área construída.

Visando a recuperação das condiçóes de equilíbrios dos sistemas biofísicos é indicada a proibição de instalaçóes humanas nas margens das lagoas Grande e Funda, de forma a coibir a implantação de loteamentos e o consequente aterro.

A recuperação da vegetação em torno das lagoas é de fundamental importância, bem como a proibição de abertura de ruas e ampliação de loteamentos principalmente nas áreas de preservação permanente, pois podem afetar processos naturais como os de acresçáo e formação de dunas e de escoamento superficial entre as zonas de cordóes. 


\section{Classe passível de ocupaçáo (ocupaçáo orientada)}

Abrange as áreas que podem ser ocupadas. Entretanto, deve-se abarcar o uso controlado, com ênfase na qualidade ambiental. Envolve as áreas tomadas por localidades, pastagens e cultivos com ocupação já estabelecida que não se encontram nas zonas de preservação, conservaçáo e recuperação estando relacionadas à expansão agropecuária e de consolidação urbana.

A deficiência na oferta de saneamento básico é notória em praticamente todas as localidades. Assim, em se tratando da implantação de infraestrutura urbana deve-se priorizar o saneamento ambiental com implantaçáo de fossas sépticas adequadas às condiçóes locais e oferta eficiente de abastecimento de água, coleta de lixo, bem como melhorias habitacionais.

\section{CENÁRIO EXPLORATÓRIO}

Baseado nas definiçóes de Oliveira e Rodrigues (2009) é apresentado o cenário exploratório (Figura 06) como subproduto da proposta de uso do cenário recomendado. Como recorte temporal, foi considerado o intervalo de 10 anos para o desenvolvimento deste cenário. As classes estipuladas são as seguintes:

\section{Área de Preservaçáo Permanente}

É constituída por todas as áreas antes pertencentes à classe Preservaçáo que segue as determinaçôes sobre as categorias de proteção da vegetação definidas em lei.

Em 2021 estarão preservadas as áreas de mangue localizadas nas margens dos cursos fluviais, as nascentes, as matas ciliares, bem como as margens das lagoas, as áreas cobertas por vegetação original de restinga, as lagoas permanentes e de regime estacional que servem de refúgio para espécies migratórias da ave-fauna, além das dunas embrionárias, móveis e em processo de fixação.

A proteção destas áreas mediante a proibição da ocupação evitará processos de degradação como assoreamento do sistema fluvial e problemas como o da erosão marinha relacionados à localização indevida de casas de veraneio e estabelecimentos comerciais nas áreas ambientalmente frágeis como de praias e de antedunas.

Em se tratando da preservação dos sistemas dunares, temse a garantia de que os processos naturais de fornecimento sedimentar, de acresçáo, de desenvolvimento das feiçóes estarão mantidos para promoverem a consequente evolução do campo.

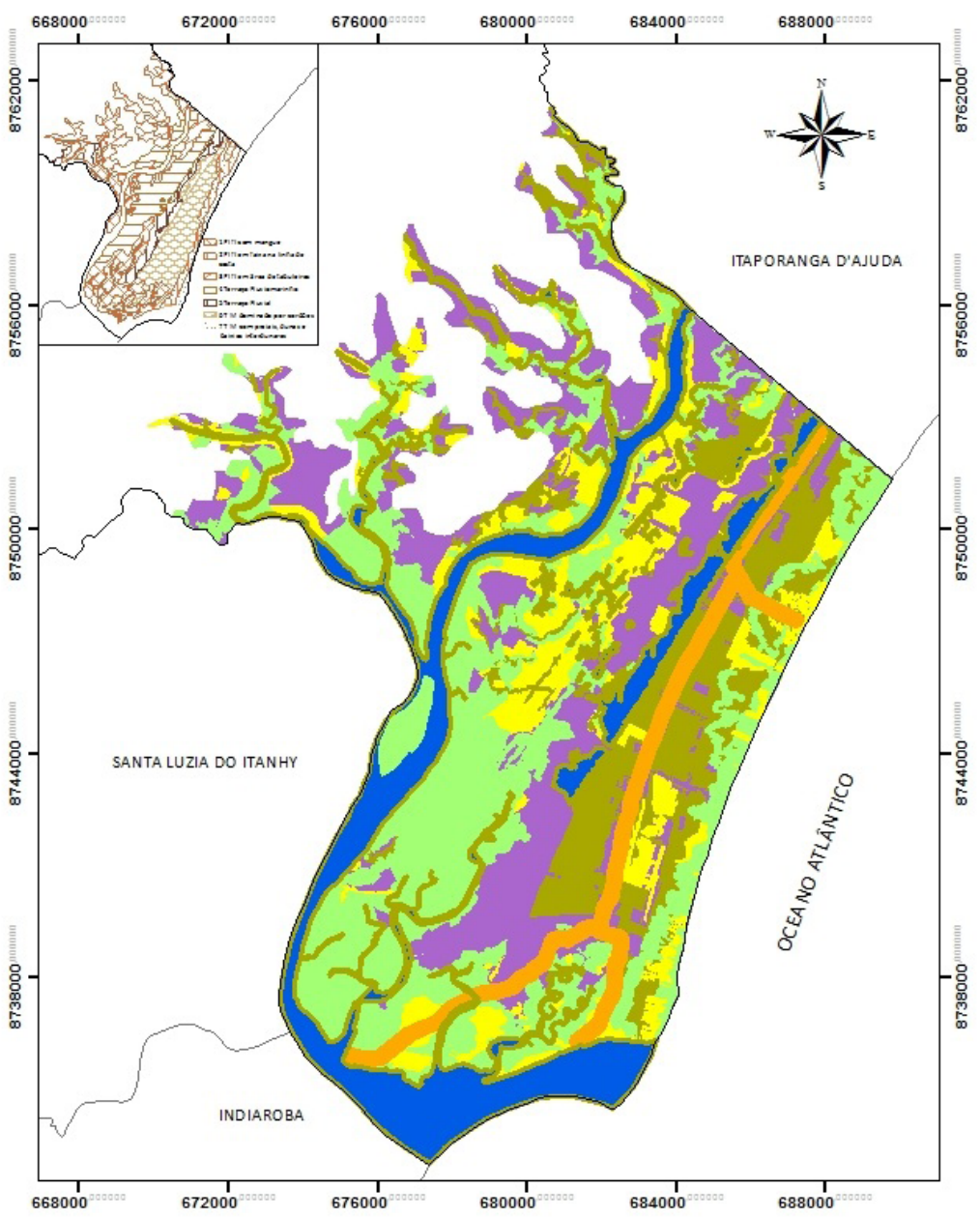

Figura 6. Cenário pretendido da Planície Costeira de Estância-SE. Figure 6. Future scenario of the Coastal Plain of the Estância-SE

\section{CENÁRIO EXPLORATÓRIO PLANÍCIE COSTEIRA DE ESTÂNCIA-SE}

Classes propostas

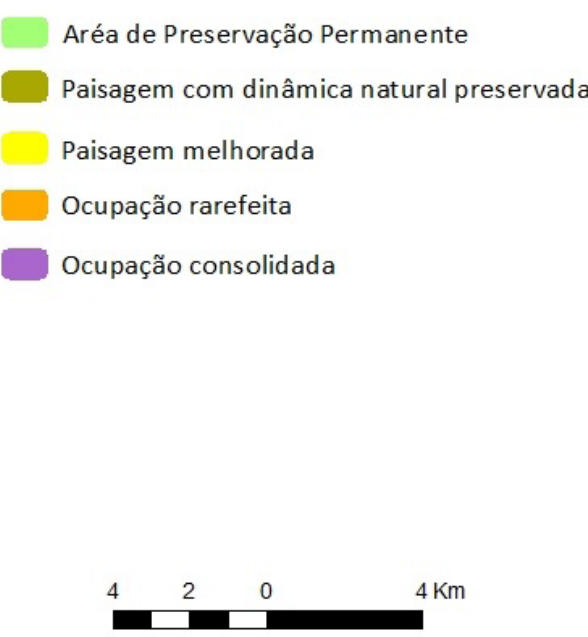

FONTE: BASE DIGITAL DOS MUNICÍPIOS LITORÂNEOS DE SERGIPE, 2003. ELABO RAÇÃO: ANÍZIA OLIVEIRA 


\section{Paisagem com dinâmica ambiental preservada}

Refere-se à classe Conservaçấo. Mantidas as áreas pertencentes a esta categoria do cenário recomendado puderam ser conservadas as características e funçóes naturais dos ambientes biofísicos.

Com a conservação dos terrenos e baixios inundáveis, o controle da ocupaçáo do solo a partir de parcelamentos ambientalmente planejados e do uso agrícola principalmente em áreas de relevo mais acidentado, haverá a conservação do solo contra os efeitos da erosão, conservação das condiçóes de vida da fauna e flora locais, manutenção das áreas de preservação permanente e do equilíbrio dos ecossistemas componentes da paisagem.

Em 2021 as atividades vinculadas ao uso residencial, comercial e turístico desenvolvidas de forma restrita e planejada não interferirão na qualidade ambiental e causarão uma baixa interferência na dinâmica natural dos ambientes com alto grau de conservação pela alta capacidade de resiliência.

\section{Paisagem melhorada}

Diz respeito à classe Recuperação proposta para o cenário recomendado. No horizonte temporal adotado, as áreas pertencentes a esta classe estarão em conformidade com a legislação ambiental.

As ações para evitar a degradação das áreas com cobertura vegetal original, somadas à recuperação da vegetação nativa das áreas desmatadas por cultivos e pastagens dentro do que rege a legislação, sobretudo da mata ciliar dos rios da Planície Fluviomarinha e da vegetação original de restinga encontrada no Terraço Marinho, permitirá, ao longo dos 10 anos, a recomposição da vegetação, antes em estágio médio e avançado de degradaçáo, e o seu enquadramento no estado em que predominam as condições de estabilidade.

A proibição de instalaçóes humanas impactantes nas margens das lagoas Grande e Funda e a recuperaçáo da vegetação do entorno possibilitará a regeneração natural da cobertura vegetal e conservação dos ecossistemas.

O controle da ocupaçáo dos terrenos naturalmente inundáveis de forma a garantir a permeabilidade permitirá escoamento natural intracordóes evitando com isso riscos à ocupação.

\section{Ocupaçáo rarefeita}

Classe que abrange toda a margem da Rodovia Estadual SE-10. Criada para enquadrar a faixa de terra ao longo da rodovia que deverá conter baixa adensamento de construçôes e população residente, pois se trata de uma classe que integra a categoria Paisagem com dinâmica ambiental preservada.

Os terrenos que fazem parte desta classe devem apresentar uma ocupação rarefeita com paisagens levemente modificadas pela atividade humana com baixo potencial de impacto.

O estímulo à ocupação de baixa densidade dá-se de forma a garantir a permanência da vegetação original e a conservação de áreas com alto valor ecológico como brejos, restingas, dunas e lagoas.

\section{Ocupaçáo consolidada}

Classe que apresenta áreas consolidadas compostas por localidades, pastagens e cultivos. Seguindo as indicações propostas na Classe Passível de ocupação definida para o cenário recomendado, haverá a consolidação das áreas predominantemente residenciais com ampliação ou implantaçáo de infraestrutura, oferta de áreas de lazer, equipamentos e serviços urbanos.

Apesar da menor exigência quanto ao nível de modificação pela atividade humana em comparação com as outras classes, a estratégia de ação corretiva e de controle da qualidade ambiental estará presente nas formas de uso e ocupação.

\section{CONCLUSÓES}

A compartimentação da Planície Costeira do município de Estância em unidades e subunidades de paisagem possibilitou um melhor entendimento da configuraçáo da paisagem em termos de elementos e processos envolvidos por meio da identificação dos níveis de ocupação e dos problemas característicos mais importantes do espaço costeiro permitindo, com isso, a compreensão de certas especificidades frente aos limites e potencialidades de cada unidade.

Assim, a compartimentação em unidades de paisagem possibilitou a compreensão dos fatores que caracterizam a dinâmica de funcionamento da Planície Costeira da área de estudo, no que se refere à associação entre os componentes naturais e antrópicos envolvidos na configuração de sua estruturação possibilitando, com isso, a proposição de alternativas de uso para os diversos níveis de fragilidades ambientais.

Considerando fatores como as práticas de uso da terra, os níveis de degradação decorrentes, o desrespeito à legislação e a consequente mudança da paisagem foi desenvolvida uma proposta de uso recomendado (cenário recomendado) mediante a análise da configuração atual do espaço pelo padrão vigente de uso e ocupaçáo. Baseado nesta proposta desenvolveu-se, a partir de Oliveira e Rodriguez (2009), o cenário exploratório (designado para se referir ao uso pretendido, com a finalidade de indicar o uso sustentável frente às perspectivas de ocupaçáo para o futuro), o qual compreende o horizonte temporal de 10 anos.

Estas proposiçóes, apresentadas como procedimentos para o planejamento do meio físico, norteiam o reconhecimento das prioridades de ação permitindo contribuir com a orientação dos usos em função do controle das pressóes antrópicas e de proposiçôes que não comprometam a integridade biofísica.

Assim, a compreensão de como se dá o funcionamento da paisagem a partir da análise dos seus sistemas componentes, da sua estrutura espacial e de suas modificações no tempo foi necessária para o desenvolvimento do cenário de uso recomendado e, com base nele, o cenário pretendido.

Tendo em vista que os critérios utilizados no ordenamento dos usos e na gestão costeira comumente desconsideram as capacidades de reaçóes e evoluçôes dos ambientais naturais urgem propostas de estudos deste tipo.

\section{BIBLIOGRAFIA}

Bittencourt, A.C.S.P.; Dominguez, J.M.L.; Martin, L.; Ferreira, Y.A. (1982) - Dados preliminares sobre a evolução paleogeográfica do Rio São Francisco.-SE/AL, durante o quaternário: influências da variação do nível do mar. IV Simpósio do Quaternário do Brasil, p. 49-68., ABEQUA, Rio de Janeiro, RJ, Brasil. 
Bolos, M. (org) (1992) - Manual de ciência del paisaje. Teoria, métodos y aplicaciones. 273p., Ed. Masson, Barcelona, Espanha. ISBN: 9788431105952.

Carvalho, M.E.S.; Fontes, A.L. (2006) - Estudo ambiental da zona costeira sergipana como subsídios ao ordenamento territorial. Revista Geonordeste (ISSN 1518-6059), ano XV (2):10-39, Núcleo de Pós-Graduação em Geografia, Universidade Federal de Sergipe, São Cristóvão, SE, Brasil. Disponível em http://200.17.141.110/pos/ geografia/geonordeste/index.php/GeoNordeste/article/ view/69/5

Costa, H.A.; Nascimento, E. (2007) - Cenários para o turismo no Brasil 2007-2010: análise da consistência metodológica e plausibilidade dos cenários. Caderno Virtual de Turismo (ISSN: 1677-6976), 7(3):46-65. Rio de Janeiro, RJ, Brasil. Disponível em http://www.ivt. coppe.ufrj.br/caderno/index.php?journal=caderno\&pag $\mathrm{e}=$ issue\&op=view\&path\%5B\%5D=25

Dias J.A.; Carmo, J.A.; Polette, M. (2009) - As Zonas Costeiras no contexto dos Recursos Marinhos. Revista de Gestão Costeira Integrada / Journal of Integrated Coastal Zone Management 9(1):3-5. Disponível em http://www. aprh.pt/rgci/pdf/RGCI-168_Prefacio.pdf

Fontes, A.L. (2007) - Relevo esolos. In:V.L.A. França \& M.T.S. Cruz (coord.), Atlas Escolar Sergipe: espaço geo-histórico e cultural, pp.69-82, Editora Grafset. João Pessoa, PB, Brasil. ISBN: 8587872451.

Freitas Filho, A. (2001) - A metodologia de construção de cenários: conceitos básicos. Workshop para prospecção em C\&T, pp.1-25, Brasília, DF, Brasil.

Meirelles, M.S.P.; Becker, B.; Egler, C.; Miranda, M.; Bragança, P.C.O.; Santos, U.P.; Campos, M.L. (1999) Metodologia para elaboração do Zoneamento EcológicoEconômico em áreas com grande influência antrópica. Embrapa Solos, Circular Técnica no 4, ISSN 1517-5146, Rio de Janeiro, RJ, Brasil. Disponível em http://www.cnps. embrapa.br/publicacoes/pdfs/circular_tecnica_4_1999_ metod_zee.pdf

Neto, J.A.B.; Ponzi, V.R.A.; Sichel, S.E. (org.) (2004) Introdução à Geologia Marinha.279p., EditoraInterciência, Rio de Janeiro, RJ, Brasil. ISBN: 8571930988.

Oliveira, P.C.E; Rodrigues, S.C. (2009) - Utilização de cenários ambientais como alternativa para o zoneamento de bacias hidrográficas: estudo da bacia hidrográfica do Córrego Guaribas, Uberlândia - MG. Sociedade \& Natureza (ISSN:1982-4513), 21(3):305-314, Instituto de Geografia da Universidade Federal de Uberlândia, Uberlândia, MG, Brasil. Disponível em http://www.seer. ufu.br/index.php/sociedadenatureza/issue/view/547

Rodriguez, J.M.M.; Silva, E.D.; Cavalcante, A.P.B. (2004) - Geoecologia das Paisagens: uma visão geossistêmica da análise ambiental. 222p., Editora UFC, Fortaleza, CE, Brasil. ISBN: 9788572821481
Santos, R.F. dos (2004) - Planejamento Ambiental: teoria e prática. 184p., Editora Oficina de Textos, São Paulo, SP, Brasil. ISBN: 9788586238628.

SEPLAN/SRH (2004) - Atlas Digital sobre Recursos Hidricos de Sergipe. CD-ROM, SEPLAN - Secretaria de Estado de Planejamento e Desenvolvimento Económico / SRH - Superintendência de Recursos Hídricos, Aracajú, SE, Brasil.

Zamboni, A.; Vilanova, R.R. (coord.) (2006) - Projeto orla: manual de gestão. 88p., Ministério do Meio Ambiente, Ministério do Planejamento, Orçamento e Gestão, Brasília, DF, Brasil. ISBN: 8577380505. Disponível em http://www.conpam.ce.gov.br/categoria 1/orla/ documentos/manual-do-orla/manualgestao-new.pdf

\section{LEGISLAÇÃO CONSULTADA:}

Lei n. 7.661/88 de 16 de maio de 1988. Institui o Plano Nacional de Gerenciamento Costeiro e dá outras providências. Disponível em http://www.planalto.gov. br/ccivil_03/leis/L7661.htm. Acesso em 20 de janeiro de 2011.

Lei No 4.771 de 15 de setembro de 1965. Institui o novo Código Florestal. Disponível em http://www.planalto. gov.br/ccivil_03/leis/L4771.htm. Acesso em 20 de janeiro de 2011.

Resolução CONAMA No 001, de 23 de janeiro de 1986 que dispóe sobre a Avaliação de Impacto Ambiental. Disponível em http://www.antt.gov.br/legislacao/Regulacao/suerg/ Res001-86.pdf. Acesso em 20 de janeiro de 2011.

Resolução CONAMA No 303, de 20 de março de 2002 que estabelece parâmetros, definiçōes e limites de Áreas de Preservação Permanente. Disponível em http://www. ambiente.sp.gov.br/legislacao/estadual/resolucoes/2002_ Res_CONAMA_303.pdf. Acesso em 20 de janeiro de 2011.

Estância. Lei No 18 de 14 de março de 2008. Institui o Código Municipal de Meio Ambiente e dá outras providências.

Estância. Lei No 28 de 02 de fevereiro de 2010. Institui diretrizes para o Parcelamento do Uso do Solo e dá outras providências.

Estância. Lei No 31 de 02 de fevereiro de 2010. Institui o Plano Diretor do Município de Estância/SE e dá outras providências.

Lei No 5.858 do Estado do Sergipe de 22 de março de 2006 que dispóe sobre a Política Estadual do Meio Ambiente e institui o Sistema Estadual do Meio Ambiente. Disponível em www.semarh.se.gov.br/modules/wfdownloads/visit. php?cid=1. Acesso em 20 de janeiro de 2011. 